\title{
Nonedible Vegetable Oil-Based Polyols in Anticorrosive and Antimicrobial Polyurethane Coatings
}

\author{
Chandrashekhar K. Patil ${ }^{1}$, Dong Wook Jung ${ }^{1}{ }^{\mathbb{D}}$, Harishchandra D. Jirimali ${ }^{2}$, Joon Hyun Baik ${ }^{3} \mathbb{( D}$, Vikas V. Gite ${ }^{4}$ \\ and Sung Chul Hong ${ }^{1, *(\mathbb{D})}$ \\ 1 HMC, Department of Nanotechnology and Advanced Materials Engineering, Sejong University, \\ Seoul 05006, Korea; chandrashekharpatil999@gmail.com (C.K.P.); jdw6297@naver.com (D.W.J.) \\ 2 Department of Chemistry, Gopal Vidya Nagar, Maliba Campus, Uka Tarsadia University, Bardoli, Surat \\ 394350, Gujrat, India; hdj739@gmail.com \\ 3 Department of Chemical and Biological Engineering, Sookmyung Women's University, Seoul 04310, Korea; \\ joonhyun@sookmyung.ac.kr \\ 4 Department of Polymer Chemistry, School of Chemical Sciences, \\ Kavayitri Bahinabai Chaudhari North Maharashtra University, Jalgaon 425001, Maharashtra, India; \\ vikasgite123@gmail.com \\ * Correspondence: sunghong@sejong.ac.kr; Tel.: +82-2-3408-3750
}

Citation: Patil, C.K.; Jung, D.W.; Jirimali, H.D.; Baik, J.H.; Gite, V.V.; Hong, S.C. Nonedible Vegetable Oil-Based Polyols in Anticorrosive and Antimicrobial Polyurethane Coatings. Polymers 2021, 13, 3149. https://doi.org/10.3390/

polym13183149

Academic Editor: Sándor Kéki

Received: 24 August 2021

Accepted: 14 September 2021

Published: 17 September 2021

Publisher's Note: MDPI stays neutral with regard to jurisdictional claims in published maps and institutional affiliations.

Copyright: (c) 2021 by the authors. Licensee MDPI, Basel, Switzerland. This article is an open access article distributed under the terms and conditions of the Creative Commons Attribution (CC BY) license (https:/ / creativecommons.org/licenses/by/ $4.0 /)$.

\begin{abstract}
This review describes the preparation of nonedible vegetable oil (NEVO)-based polyols and their application in anticorrosive and antimicrobial polyurethane (PU) coatings. PUs are a class of versatile polymers made up of polyols and isocyanates. Renewable vegetable oils are promising resources for the development of ecofriendly polyols and the corresponding PUs. Researchers are interested in NEVOs because they provide an alternative to critical global food issues. The cultivation of plant resources for NEVOs can also be popularized globally by utilizing marginal land or wastelands. Polyols can be prepared from NEVOs following different conversion routes, including esterification, etherification, amidation, ozonolysis, hydrogenation, hydroformylation, thio-ene, acrylation, and epoxidation. These polyols can be incorporated into the PU network for coating applications. Metal surface corrosion and microbial growth are severe problems that cause enormous economic losses annually. These problems can be overcome by NEVO-based PU coatings, incorporating functional ingredients such as corrosion inhibitors and antimicrobial agents. The preferred coatings have great potential in high performance, smart, and functional applications, including in biomedical fields, to cope with emerging threats such as COVID-19.
\end{abstract}

Keywords: nonedible vegetable oil; polyol; polyurethane; coating; anticorrosive; antimicrobial

\section{Introduction}

The progressive dwindling of fossil fuel resources, coupled with the drastic increase in fossil fuel prices, has sparked feverish activity in the search for alternatives based on renewable resources. Polyols are typically viscous materials that can be converted into value-added polymers. The use of vegetable oils (VOs) in the preparation of polyols has thus gained high attention due to their renewability, low cost, and wide availability. VOs are classified into two general categories, edible and nonedible VO (NEVO). Of the oils, NEVOs have become more attractive for the development of polyols due to their nonfood nature, which is critical for preserving the global food supply. The conversion of NEVOs into polyols can be conducted through various chemical pathways, such as epoxidation, thioene, ozonolysis, hydrogenation, hydroformylation, polyesterification, polyetherification, transesterification, and amidation [1].

Polyurethane (PU) is a group of versatile polymers invented by Otto Bayer and coworkers in 1937 [2]. As PU is mainly prepared through polyaddition reaction between polyols and multifunctional isocyanates (Figure 1), PU properties can roughly be controlled 
by the chemical nature and combinations of the polyols and isocyanates, allowing them to be used in various fields including foams (rigid and flexible), adhesives, sealants, and elastomers [2,3]. Due to the presence of urethane groups in their chemical structures, PU particularly possesses excellent chemical resistance, abrasion resistance, thermal stability, and adhesion characteristics, which allow them to be used as coating materials in medical, building, construction, automotive, packaging, marine, furnishing, and electronic fields $[4,5]$.

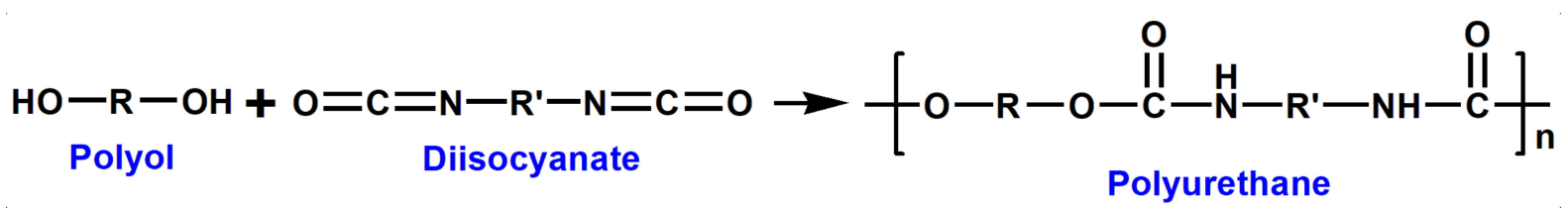

Figure 1. Schematic representation of the preparation of PU from polyol and diisocyanate.

In this review, different NEVOs and NEVO-based polyols are demonstrated. Preparation of NEVO-based polyols through different chemical pathways are also summarized. The aspects of NEVOs that are covered in this article are their origin, fatty acid composition, physicochemical properties, conversion routes to polyols, and the corresponding PU coatings, including NEVO-based functional PU coatings with anticorrosive and antimicrobial performances. The basics of PUs including diisocyanates and polyols are also introduced.

\section{Diisocyanates and Polyols for Polyurethanes}

\subsection{Diisocyanates for Polyurethanes}

Diisocyanates can be classified into aromatic, aliphatic, and cyclo-aliphatic (Figure 2). Most common diisocyanates are aromatic diisocyanates such as toluene diisocyanate (1, TDI) and methylene diphenyl diisocyanate (2, MDI). Aliphatic diisocyanates include 1,6hexamethylene diisocyanate (3, HDI) and 2,2,4-trimethylhexamethylene diisocyanate $(4$, TMDI), while 4, $4^{\prime}$-dicyclohexylmethane diisocyanate $\left(5, \mathrm{H}_{12} \mathrm{MDI}\right)$ and isophorone diisocyanate (6, IPDI) are major cycloaliphatic diisocyanates. Polymeric methylene diphenyl diisocyanate (7, PMDI) can also be used. Although aromatic diisocyanates are comparatively less expensive and more reactive than the aliphatic counterpart [6], aromatic diisocyanates often suffer from yellowing and degradation issues under environmental conditions (e.g., UV light). Aliphatic or cycloaliphatic diisocyanates are thus preferred for outdoor applications. The origin of the most of diisocyanates is petroleum resources. However, several reports have claimed that the preparation of diisocyanates is from renewable resources through Curtius rearrangement, including 1,7-heptamethylene diisocyanate and 1,16-diisocyanatohexadec-8-ene from oleic acid [7-9].

\subsection{Conventional Polyols for Polyurethanes}

Polyols are low-to-moderate molecular weight precursors having two or more hydroxyl groups per molecule. Different types of polyols are commercially available, including polyether, polyester, polycarbonate, polyamides, and acrylic polyols. Most of conventional polyols are obtained from petroleum sources, as exemplified in Figure 3.

Polyester polyols are prepared through different pathways such as acidolysis of epoxides, esterification of acids, and alcoholysis of anhydrides. Polycaprolactone is conventional polyester polyol, which is obtained from ring opening reaction of $\varepsilon$-caprolactone and glycols in the presence of stannous octate as a catalyst. Ring opening oligomerizations of ethylene or propylene oxides afford hydroxyl-terminated polyether polyols. Hyperbanched polyether polyols are also prepared through multibranching polymerizations [10-12] Poly(tetramethylene ether) glycol is also obtained from the ring opening polymerization of tetrahydrofuran. Acrylic polyols are obtained by free radical polymerization of suitable acrylic monomers. 
<smiles>Cc1ccc([N+](=O)[O-])cc1[N+](=O)[O-]</smiles>

(1, TDI)<smiles>O=NC1CCC(CC2CCC(N=O)CC2)CC1</smiles>

(5, $\left.\mathrm{H}_{12} \mathrm{MDI}\right)$<smiles></smiles>

(6, IPDI)<smiles>C=C/C(=C\C)[N+](=O)[O-]</smiles>

(3, HDI)<smiles>CC(CC[N+](=O)[O-])CC(C)(C)CN=O</smiles>

(4, TMDI)

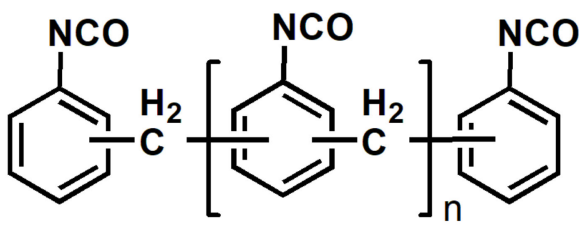

(7, PMDI)

Figure 2. Common aromatic, aliphatic, and cycloaliphatic diisocyanates for PUs.<smiles>[R20]OC(=O)O[R](=O)O[R]O</smiles>

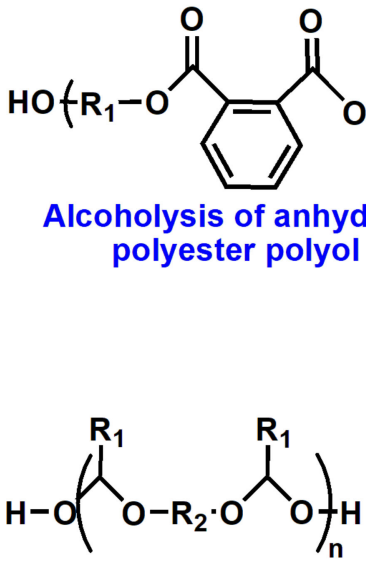

Epoxy and diol based polyether polyol

$$
\text { OO- }
$$

Ring opening polyether polyol

Diol and diacid based polyester polyol

Figure 3. Conventional polyols for PUs from petroleum resources.

\subsection{Polyols from Renewable Resources for Polyurethanes}

Despite the many advantages, there is a distinct limitation of conventional polyol. Due to diminishing fossil fuels, the rising prices of petroleum based raw materials, and the increase in environmental concerns, academics and industries have been exploring the replacement of petroleum resources with renewable resources. Renewable resources include VOs, cellulose, wood, carbohydrates, starch, and sorbitol [13-17]. Polysaccharides 
are long chain polymeric carbohydrates formed by monosaccharide units through the glycosidic bond. The examples of polysaccharides are starch, cellulose, and chitosan, etc., which are derived from nature as a structural material to construct cell walls of crustaceans, plants, and other agricultural feed stocks. The polysaccharides have been used for PUs, including cellulose nanocrystal and starch for PU coatings [18-20].

Among renewable resources, VOs are triglycerides obtained from plants, seeds, and other agricultural feedstocks (Figure 4). Soybean, cotton, palm, sunflower, groundnut, olive, rice bran, cotton seed, and rapeseed oils are falling in the category of edible oils (Figure 5) [21]. The production of edible oils varies depending on the climate and soil conditions, such as palm oil in Southeast Asia, rapeseed oil in Canada, soybean oil in US, coconut oil in Philippines, sunflower oil in Europe, cotton seed oil in India, etc. [22]. However, the rapidly growing world population and extensive human consumption of edible oils may cause significant problems, including starvation in developing countries and higher prices of edible VOs than of fossil fuels.

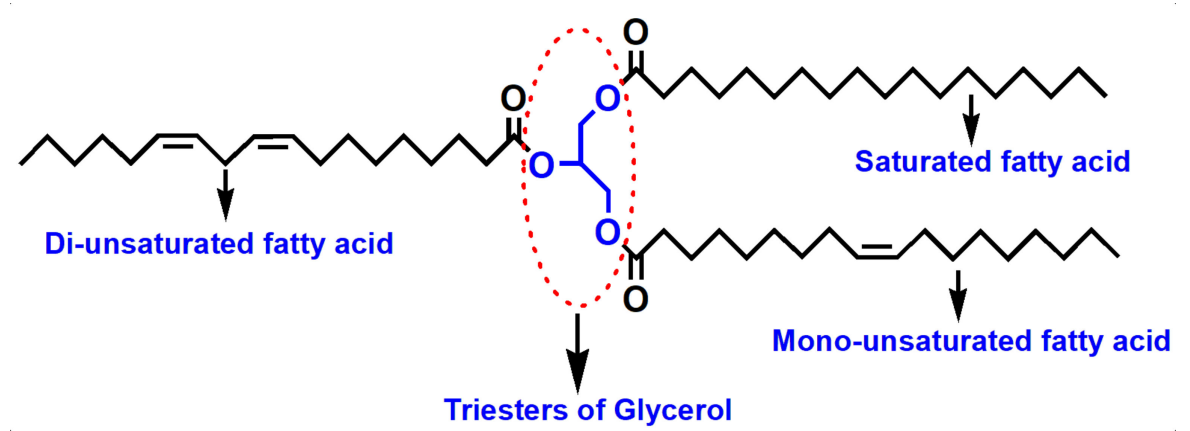

Figure 4. Schematic representation of VOs (triglyceride).

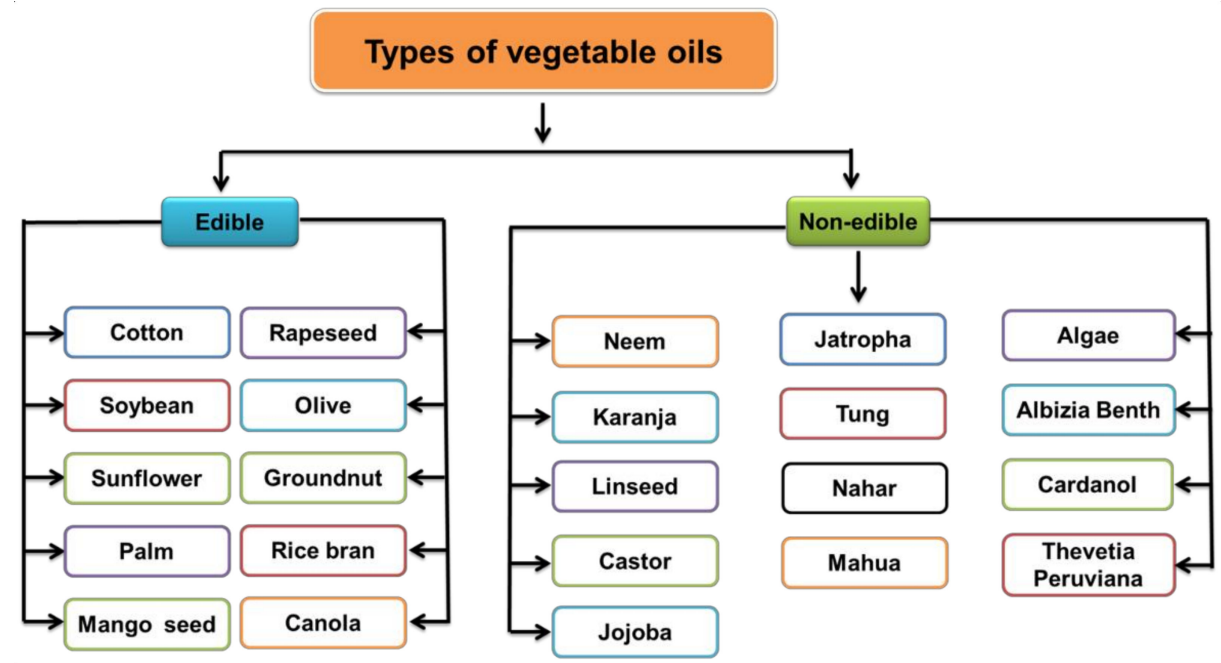

Figure 5. Examples of edible and nonedible VOs.

\section{Nonedible Vegetable Oils for Polyols}

\subsection{Nonedible Vegetable Oils}

The common NEVOs used in the preparation of polyols are listed below. The NEVOs and their fatty acid compositions along with physicochemical properties are presented in Tables 1 and 2, respectively. Important examples of NEVOs include algae oil (AO), linseed oil (LO), neem seed oil (NO), pongamia glabra seed oils (PO; karanja oil, $\mathrm{KO}$ ), Nahar seed oil (NAO), castor oil (CO), Albizia benth seed oil (ABO), tung oil (TO), mahua oil (MO), Thevetia peruviana seed oil (TPO), jojoba oil, cashew nutshell oil (cardanol), and jatropha oil (JO) (Figure 5) [23-25]. 
Table 1. Fatty acid composition of NEVOs.

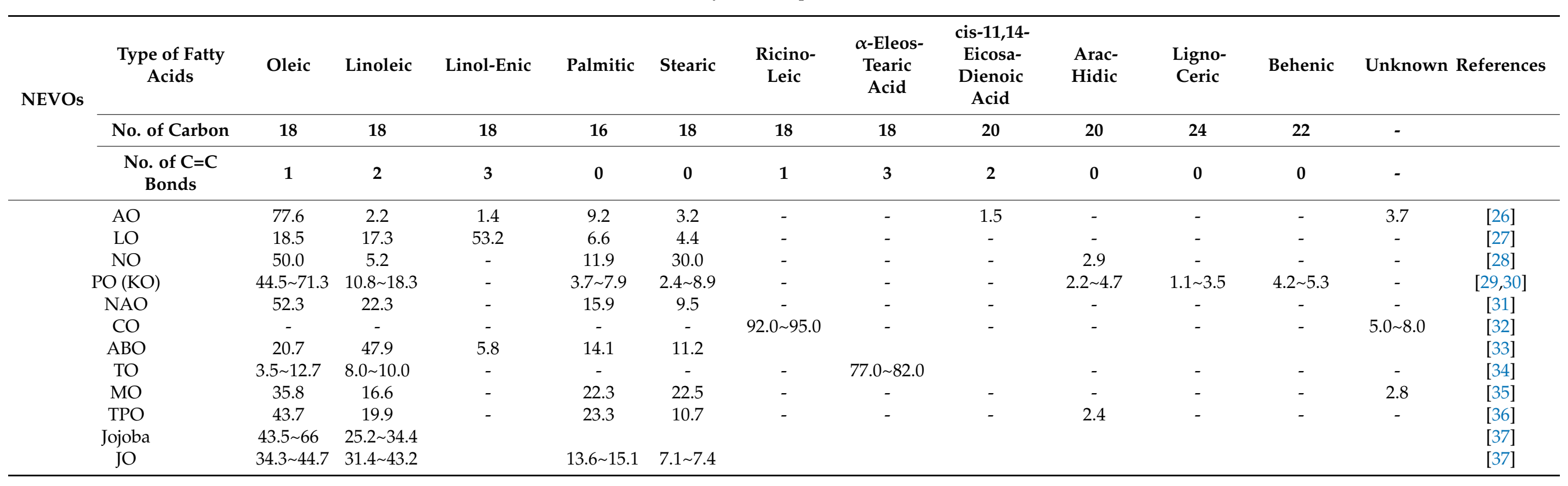


Table 2. Physicochemical characteristics of common NEVOs.

\begin{tabular}{|c|c|c|c|c|c|c|c|}
\hline NEVOs & Specific Gravity $\left(\mathrm{g} / \mathrm{cm}^{3}\right)\left(25^{\circ} \mathrm{C}\right)$ & Refractive Index & $\begin{array}{c}\text { Saponi-Fication Value } \\
(\mathrm{mg} \mathrm{KOH} / \mathrm{g})\end{array}$ & $\begin{array}{l}\text { Iodine Value } \\
\text { (g of } I_{2} / 100 \mathrm{~g} \text { ) }\end{array}$ & $\begin{array}{l}\text { Acid Value } \\
(\mathrm{mg} \mathrm{KOH} / \mathrm{g})\end{array}$ & $\begin{array}{l}\text { Hydroxyl Value } \\
\text { (mg KOH/g) }\end{array}$ & References \\
\hline $\mathrm{AO}$ & N.A. ${ }^{a}$ & N.A. ${ }^{a}$ & 193 & 85 & 0.2 & - & [26] \\
\hline LO & 0.896 & 1.478 & 160 & 181 & 8.3 & - & {$[38]$} \\
\hline $\mathrm{PO}(\mathrm{KO})$ & 0.938 & 1.467 & 182 & 89.9 & 11.5 & - & {$[30]$} \\
\hline $\mathrm{NAO}$ & 0.890 & 1.473 & 260 & 89.3 & 14.3 & - & {$[30,31,39]$} \\
\hline $\mathrm{CO}$ & 0.913 & 1.474 & 185 & 82 & 0.6 & 165 & {$[40,41]$} \\
\hline $\mathrm{ABO}$ & 0.915 & 1.473 & 185 & 104.5 & 8.1 & 0.3 & [33] \\
\hline $\mathrm{MO}$ & 0.904 & 1.477 & 187 & 62.4 & 0.4 & & [35] \\
\hline $\mathrm{TPO}$ & 0.912 & 1.464 & 121 & 71.4 & 0.66 & - & [30] \\
\hline Jojoba & 0.866 & 1.464 & 100 & 95 & 2.0 & - & {$[43,44]$} \\
\hline Cardanol & $0.941 \sim 0.924$ & $1693 \sim 1686$ & $47 \sim 58$ & $215 \sim 235$ & $12.1 \sim 15.4$ & $170 \sim 250$ & [45] \\
\hline $\mathrm{JO}$ & 0.903 & 1.475 & 190 & 97 & 2.1 & - & {$[40,46]$} \\
\hline
\end{tabular}


NEVOs can be incorporated in industrial usage due to their low cost; ability to be produced worldwide on marshlands, marginal lands, and wastelands, including under arid/semiarid conditions; and easy cultivation without disturbing food value chains because of toxic ingredients [22]. For example, NO contains azadirachtin, which has an irritating odor, while $\mathrm{KO}$ contains flavonoids, such as karanjin, pongamol, tannin and karanjachromene [23]. CO contains ricin, a toxin that may cause fatal gastroenteritis and fever [47]. JO is nonedible because it contains protein curcin and phorbol esters [22]. TPO contains cardiac glycosides, or cardiac toxins, as well as thevetin A, thevetin B, and peruvoside, which have adverse impacts on the heart by inhibiting the sodium-potassium adenosine-triphosphatase enzyme systems [48].

Approximately 75 nonedible plant species contain more than $30 \%$ oils, which can be obtained mainly from their seeds (Figure 6) $[22,39,49]$.

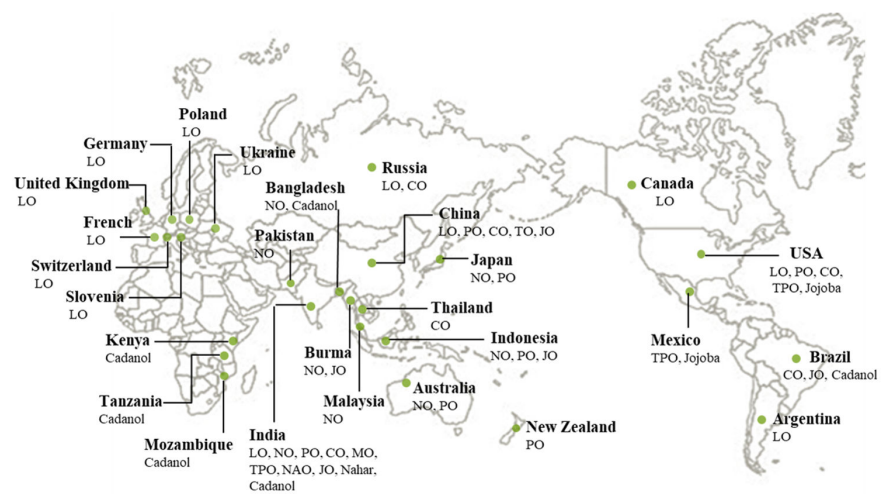

Figure 6. Global growing locations of nonedible oilseed crops.

$\mathrm{AO}$ is extracted from algae or microalgae and has been a promising candidate for NEVO. The high production possibility of AO is due to the presence of several algae species with high growth rates in many places around the world [50]. Out of 40,000 identified species of algae, microalgae are one of the fastest growing species and oil content of some species exceeds $80 \%$ of the dry weight of algae biomass. Oil obtained from microalgae accounts for around 58,700 L/ha [51]. The fatty acid composition of AO shows high percentage of oleic $(77.6 \%)$ and linoleic $(2.2 \%)$ acids, followed by linolenic $(1.4 \%)$, palmitic $(9.2 \%)$, stearic $(3.2 \%)$, cis-11,14-eicosadienoic acid $(1.5 \%)$, and other unfamiliar fatty $(3.7 \%)$ acids (Table 1) [26].

LO is another important NEVO produced largely in Canada, followed by Russia, China, the USA, India, Argentina, and some parts of Europe [37,52-54]. LO contains a high percentage of unsaturated fatty acids, viz. linolenic acid (53.2\%), followed by oleic (18.5\%) and linoleic (17.3\%) acids, along with saturated fatty acids, such as palmitic $(6.6 \%)$ and stearic (4.4\%) acids (Table 1$)$. In comparison with other VOs, LO contains a high level of unsaturated acids ( $\alpha$-linolenic), which are responsible for its poor oxidation stability, high rate of polymerization, and drying properties [27]. LO is one of the most popular NEVOs to be used in polymer field. Reports have been published on the development of different types of polyols from LO and their applications in polyester/PU coatings [38,55-65].

Neem trees (Azadirachta indica A. Juss) are cultivated in India on arid and dry land. The kernel (seed) of neem trees can be used to extract NO, which contains azadirachtin as a toxic active ingredient. NO is abundantly available in India and the Indian continent, with a production rate of 18,000 per tones in arid land. [28]. NO is also found in several Asian countries, such as Sri Lanka, Pakistan, Bangladesh, Japan, Malaysia, Indonesia and Burma, and in the tropical regions of Australia [37]. NO contains both saturated and unsaturated fatty acids, namely, palmitic $(11.9 \%)$, stearic $(30.0 \%)$, arachidic $(2.9 \%)$, oleic $(50.0 \%)$, and linoleic (5.2\%) acids (Table 1) [28]. NO has many applications in different areas, such as agriculture [66], pharmaceuticals [67], and biodiesel [68,69]. Currently, NO is adopted often in the preparation of functional polymeric coatings. 
PO is also known as KO and is extracted from karanja seeds. Approximately 110,000 tons of seeds are collected every year in India, especially in the eastern states of India and other states, such as Andhra Pradesh, Karnataka, Tamil Nadu, Assam, and Western Ghats [70]. PO is also found in China, Japan, Australia, New Zealand, and the USA [29,30]. PO possesses unsaturated and saturated fatty acids; in particular, it contains oleic acid (44.5 71.3\%) at higher percentages than linoleic $(10.8 \sim 18.3 \%)$, stearic $(2.4 \sim 8.9 \%)$, palmitic $(3.7 \sim 7.9 \%)$, behenic $(4.2 \sim 5.3 \%)$, arachidic $(2.2 \sim 4.7 \%)$, and lignoceric $(1.1 \sim 3.5 \%)$ acids $[29,30]$. Crude PO has also been used to produce biodiesel by the methyl ester route for substitution of petroleum-based fuels [71,72].

Nahar (Mesua ferrea L.) is an oil seed plant in that is widely grown in the northeastern region of India and contains a high oil percentage $(70 \sim 75 \%)$. The fatty acid composition of NAO comprises primarily oleic (52.3\%) and linoleic $(22.3 \%)$ acids, followed by low levels of palmitic (15.9\%) and stearic (9.5\%) acids [31]. Although many polyesters or epoxy resins from NAO have been reported $[39,73,74]$, only a few examples can be found for PU resin with NAO [75-78].

$\mathrm{CO}$ is unique among all VOs due to the presence of hydroxyl groups on ricinoleic acid (92 95\%) [32]. CO is cheap, widely available, and in high demand due to its inherent hydroxyl groups [32]. The main countries that produce CO are India, China, Brazil, Thailand, and Russia. Castor is grown on about $1.26 \times 10^{6}$ ha area with about $1.14 \times 10^{6}$ tons production and world average productivity is about 0.90 ton/ha [79].

ABO contains linoleic (47.9\%) and oleic (20.7\%) acids as major fatty acids, followed by palmitic (14.1\%), stearic (11.2\%), and linolenic (5.8\%) fatty acids [33]. TO is also known as Chinese wood oil and is extracted from tung tree seeds. TO contains $\alpha$-eleostearic acid $(77.0 \sim 82.0 \%)$ as a major fatty acid, followed by oleic (3.5 12.7\%) and linoleic (8.0 10.0\%) acids [34]. TO has fast drying properties and a fast oxidative polymerization capability in the presence of oxygen, which can be catalyzed by cobalt $[80,81]$. In addition to its use in coating formulations, TO is also used in the preparation of PU composites, emulsions, and foams [82].

MO is extracted from mahua seeds (Madhuca indica). MO is found abundantly in tropical regions of India, Madhya Pradesh, Andhra Pradesh, Bihar, Gujarat, Uttar Pradesh, and Odisha. The main fatty acid composition of $\mathrm{MO}$ is oleic (35.8\%), stearic $(22.5 \%)$, palmitic $(22.3 \%)$, and linoleic $(16.6 \%)$ fatty acids [35].

Thevetia peruviana (yellow oleander) is an ornamental plant belonging to the Apocynaceae family and is found on the American, Asian and African continents and in regions of India, specifically in Assam [83]. TPO contains both saturated (36.4\%) and unsaturated $(63.6 \%)$ fatty acids, including oleic $(43.7 \%)$, palmitic $(23.3 \%)$, linoleic $(19.9 \%)$, stearic $(10.7 \%)$, and arachidic $(2.4 \%)$ acids $[36,83]$. Only a limited report is available on the utilization of $\mathrm{TPO}$ in polymer preparation.

Jojoba is native to the California deserts, Mexico, and Arizona [84]. The jojoba tree is from the Simmondsiaceae family, and the seed contains approximately 40 50 wt.\% oil with a fatty acid composition of oleic acid (43.5 66\%) and linoleic acid (25.2 34.4\%) [37].

Cashew nutshell liquid (also called cashew oil, cashew nutshell oil) is a natural alkenyl phenolic compound obtained from cashew nutshells as an agricultural byproduct. Cashew nutshell liquid has a low cost, is abundantly available (450,000 metric tons per year), and contains linear unsaturated phenolic derivatives, viz. cardanol, 2-methyl-cardol, anacardic acid, and cardol [85]. The production of cashew nutshell liquid has increased with the increase in cashew nut tree (Anacardium occidentale L.) plantations in Brazil and other parts of the world, such as India, Bangladesh, Kenya, Tanzania, Mozambique, tropical regions of Africa, and Southeast/Far-East Asia [85,86]. It contains 18 27\% phenolic moiety that has unsaturated 15-carbon chain $[87,88]$. Cashew nutshell liquid has been used in many industrially important chemicals because of its unique structure and desirable properties, such as hydrophobicity, flexibility, weatherability, and acid and alkali resistances [89]. The reactive phenolic hydroxyl group and an unsaturated C15 alkyl chain make cashew 
nutshell liquid a good platform for chemical modifications in the form of polyols that can be converted into coatings, foams, and paints [90-94].

Jatropha is known to have 170 different species, of which 66 species have been identified as major sources of oil and are cultivated in Central/South America, Africa, India, and Southeast Asia, covering a global area of approximately 900,000 ha [95]. More than 85 percent of jatropha plantations are in Asia, chiefly Myanmar, India, China, and Indonesia. Africa accounts for around 12 percent or approximately 120,000 ha, while Latin America has approximately 20,000 ha of jatropha, mostly in Brazil [95]. JO contains mainly unsaturated fatty acid, such as oleic (34.3 44.7\%), linoleic (31.4 43.2\%), palmitic (13.6 15.1\%), and stearic acids (7.1 7.4\%) [37].

\subsection{Chemical Transformation of Nonedible Vegetable Oils to Polyols}

Polyols can be prepared from NEVOs by esterification, etherification, amidation, epoxidation, etc., taking advantage of its functional groups in their structures (Figure 4). The preparation of polyols from NEVOs is quite similar to that from edible VOs, following several pathways as schematically demonstrated in Figure 7.

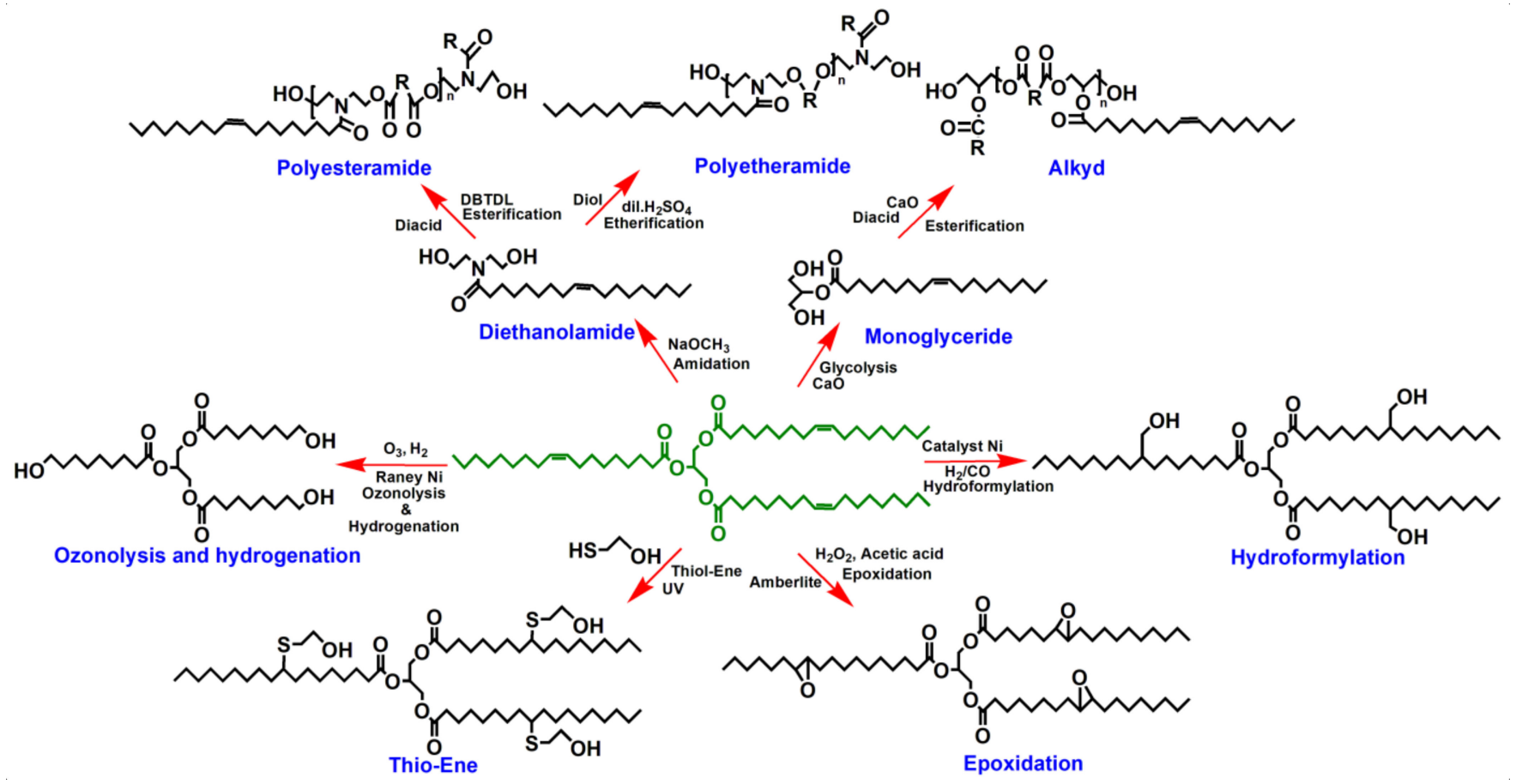

Figure 7. Schematic representation of the preparation of different polyols from VOs.

One of the most prominent routes is through polyesteramide (PEsA), which can be prepared by esterification of VO-based diethanolamides with dicarboxylic acids or anhydrides [96]. Prior to the preparation of PEsAs, diethanolamides are prepared by the amidation of VOs by reacting them with diethanolamine in the presence of a suitable catalyst $[96,97]$. Polyetheramide (PEtA) is another class of polyols that first requires the preparation of diethanolamides, which are further reacted with diols to be converted into PEtAs [50]. Alkyds are the oldest polymeric resins prepared with VOs and contain ester moieties in their polymeric chains [16].

Polyols with terminal primary hydroxyl groups can be prepared by the ozonolysis route by treating VOs with ozone to form ozonide and further reduction with Raney nickel [97]. Polyols can also be prepared by the hydroformylation process of VOs with the addition of hydroxymethyl groups to the carbon-carbon double bonds of the fatty acid chains. $\mathrm{VO}$ reacts with a mixture of $\mathrm{CO}$ and $\mathrm{H}_{2}$ in the presence of a catalyst to give aldehydes and is further reduced with $\mathrm{H}_{2}$ to obtain hydroxyl groups [97]. In the 
hydroformylation process, the most frequently used catalysts are cobalt carbonyl complexes selectively modified by tertiary phosphate ligands and tertiary phosphine rhodium carbonyl species [13].

Epoxidation of VOs is one of the most popular routes for the preparation of polyols and can be achieved by different processes, such as epoxidation by peracids, hydrogen peroxide, dioxirane, phase transfer catalysts, and chemoenzymatic species $[16,21,72,97,98]$. Generally, epoxidation is carried out at the carbon-carbon double bonds of fatty acids using a peracid with hydrogen peroxide and acetic/formic acid, followed by opening of the oxirane ring with proton donors.

VO-based polyols can also be prepared by a single-step thiol-ene reaction in VOs with thiol compounds under ultraviolet light for the conversion of double bonds into polyols [45,99-102]. Acrylation, vinylation, metallation, and other chemical pathways can also be employed for the preparation of polyols to produce better dried, glossy, scratchresistant, impact-resistant, flexible, and corrosion-resistant coatings. The presence of hydroxyl, ester, oxirane, amide, carbonyl, acrylic, carboxyl, and urethane groups may provide good adhesion characteristics of the corresponding coatings to substrates.

\section{Nonedible Vegetable Oil-Based Polyurethane Coatings}

Corrosion and microbial growth on metal surfaces are severe problems that cause enormous economic losses annually in many sectors, including in marine, medical, packaging, construction, transportation, oil refining, pipelines, and petrochemical industries. Corrosion is damaging to industrial machines, power plants, ships, bridges, water treatment plants, etc. Trillions of dollars are spent on maintenance every year. Antiviral coatings on personal protective equipment are currently in high demand for vaccines and other medical applications due to COVID-19. Biofouling of marine coatings is another important issue pertaining to microbial growth that results in tremendous economic losses (approximately $\$ 30 \sim 50$ billion every year) [26]. Table 3 summarizes the synthetic routes for PU coatings from different NEVOs. The various ingredients used to afford anticorrosion and antibacterial functionalities to PU coatings are also summarized.

Table 3. Synthetic intermediate (or pathway) and active ingredients of anticorrosive and antibacterial PU coatings.

\begin{tabular}{|c|c|c|c|c|}
\hline NEVOs & Synthetic Intermediate/Pathway & Functional Ingredients & Functionality & References \\
\hline \multirow{4}{*}{$\mathrm{AO}$} & PEsA & $\begin{array}{c}\text { Mercaptosuccinic acid, } \\
\text { thiodipropionic acid }\end{array}$ & $\begin{array}{l}\text { Antibacterial, } \\
\text { anticorrosive }\end{array}$ & [103] \\
\hline & PEsA, alkyd & $\begin{array}{c}\text { Phthalic anhydride, itaconic, maleic, } \\
\text { dimer acids }\end{array}$ & $\begin{array}{l}\text { Antibacterial, } \\
\text { anticorrosive }\end{array}$ & [26] \\
\hline & PEsA & $\begin{array}{c}\text { Ricinoleic acid, silver } \\
\text { (Ag)-hydroxyapatite (HAP) } \\
\text { nanoparticles (NPs) }\end{array}$ & $\begin{array}{l}\text { Antibacterial, } \\
\text { anticorrosive }\end{array}$ & [104] \\
\hline & PEtA & Fatty amide & $\begin{array}{l}\text { Antibacterial, } \\
\text { anticorrosive }\end{array}$ & {$[50]$} \\
\hline \multirow{10}{*}{$\mathrm{LO}$} & Epoxidation, hydroxylation & \multirow{2}{*}{$\begin{array}{l}\text { LO, TDI } \\
\text { Long hydrocarbon chains of fatty } \\
\text { triester residues }\end{array}$} & Anticorrosive & [105] \\
\hline & Epoxidation, hydroxylation & & Antibacterial & [106] \\
\hline & $\begin{array}{l}\text { Epoxidation, hydroxylation, } \\
\text { polyesterification }\end{array}$ & Boric acid & Anticorrosive & [107] \\
\hline & Epoxidation, esterification & Copper acetate & Antibacterial & [108] \\
\hline & Epoxidation, carbonation & Hydroxyl groups of nonisocyate PU & Anticorrosive & [109] \\
\hline & PEsA & Fatty amide, pyridine & Anticorrosive & [63] \\
\hline & PEsA & Fatty amide, EDTA & Anticorrosive & {$[62]$} \\
\hline & PEsA & Fatty amide, aluminium hydroxide & Anticorrosive & [110] \\
\hline & PEsA & Fatty amide & Anticorrosive & [111] \\
\hline & PEtA & Fatty amide, resorcinol & Anticorrosive & {$[64]$} \\
\hline
\end{tabular}


Table 3. Cont.

\begin{tabular}{|c|c|c|c|c|}
\hline NEVOs & Synthetic Intermediate/Pathway & Functional Ingredients & Functionality & References \\
\hline & PEtA & Fatty amide, $\mathrm{Fe}_{2} \mathrm{O}_{3} \mathrm{NPs}$ & Anticorrosive & [112] \\
\hline & Fatty amide & Fatty amide, poly(1-naphthylamine) & Anticorrosive & [113] \\
\hline & Diethanolamine & Fatty amide & Anticorrosive & [65] \\
\hline & Diethanolamide & $\begin{array}{l}\text { Fatty amide, tetraethoxyorthosilicate } \\
\text { (TEOS) }\end{array}$ & Anticorrosive & [114] \\
\hline & Polyesterification & - & Antibacterial & [115] \\
\hline & Alkyd & Hyperbranching structure & Anticorrosive & [116] \\
\hline \multirow{5}{*}{ NO } & Epoxidation & Quinoline microcapsule & Anticorrosive & [117] \\
\hline & PEtA & Fatty amide, $\mathrm{TiO}_{2} \mathrm{NP}$ & Anticorrosive & [118] \\
\hline & Fatty amide & Diethanolamine & Anticorrosive & [119] \\
\hline & Fatty amide & Fatty amide, piperazine & Anticorrosive & [120] \\
\hline & Alkyd & $\begin{array}{l}\text { Anhydride, itaconic, and dimer fatty } \\
\text { acids }\end{array}$ & Anticorrosive & [121] \\
\hline \multirow{7}{*}{$\mathrm{PO}(\mathrm{KO})$} & Epoxidation, hydroxylation & $\begin{array}{l}\text { Bioflavonoids-karanjin and } \\
\text { pongamol }\end{array}$ & Antibacterial & [106] \\
\hline & Epoxidation, acrylation & Acrylic acid, graphene oxide (GOx) & $\begin{array}{l}\text { Antibacterial, } \\
\text { anticorrosive }\end{array}$ & [122] \\
\hline & Monoglyceride, polyol mixture & - & Anticorrosive & [123] \\
\hline & PEsA & $\begin{array}{c}\text { Fatty amide, ethylene glycol } \\
\text { tetraacetic acid }\end{array}$ & Anticorrosive & [124] \\
\hline & PEsA & Fatty amide & Anticorrosive & [111] \\
\hline & PEtA & $\begin{array}{c}\text { Fatty amide, ethane } \\
\text { 1,2-di(azomethine) Bisphenol }\end{array}$ & Anticorrosive & [125] \\
\hline & PEsA, boronation & Fatty amide, boric acid & Anticorrosive & [126] \\
\hline NAO & Polyol mixture & Fatty amide & Anticorrosive & [75] \\
\hline \multirow{18}{*}{$\mathrm{CO}$} & - & $\begin{array}{l}\mathrm{COOH} \text { functionalized carbon } \\
\text { nanorods }\end{array}$ & Anticorrosive & [127] \\
\hline & Acrylation & Alkoxy silane & Anticorrosive & [128] \\
\hline & Monoglyceride & - & Anticorrosive & [32] \\
\hline & Monoglyceride & Trimer of isocyanate & Anticorrosive & [129] \\
\hline & Polyol mixture & $\begin{array}{c}\text { 3-Amino propyl trimethoxy silane, } \\
\text { 3-glycidoxy propyl trimethoxy } \\
\text { silane }\end{array}$ & Antibacterial & [130] \\
\hline & Polyol mixture & $\begin{array}{c}\text { Benzyl triethanol ammonium } \\
\text { chloride }\end{array}$ & Antibacterial & [131] \\
\hline & Polyol mixture & Poly(epichlorohydrin)-triol, PMDI & $\begin{array}{l}\text { Antibacterial, } \\
\text { anticorrosive }\end{array}$ & [132] \\
\hline & Polyol mixture & Red iron oxide pigment & anticorrosive & [133] \\
\hline & Esterification & Boric acid, phthalic anhydride & Anticorrosive & [134] \\
\hline & Transesterification & Zinc flakes & Anticorrosive & [135] \\
\hline & Transesterification & Tannin & Anticorrosive & {$[136,137]$} \\
\hline & Transesterification & - & Anticorrosive & [40] \\
\hline & Transesterification, polyol mixture & Pentaerythritol, polycaprolactone, & Antibacterial & [138] \\
\hline & $\begin{array}{l}\text { Transesterification, } \\
\text { copolymerization }\end{array}$ & Bis(4-aminophenyl)sulfone & Anticorrosive & {$[139,140]$} \\
\hline & PEsA & Fatty amide, $\mathrm{TiO}_{2}$ & $\begin{array}{l}\text { Anticorrosive, } \\
\text { antibacterial }\end{array}$ & [141] \\
\hline & PEsA & Fatty amide & Anticorrosive & [111] \\
\hline & Hydrolysis, condensation & TEOS & $\begin{array}{l}\text { Anticorrosive, } \\
\text { antibacterial }\end{array}$ & [142] \\
\hline & Epoxidation & $\begin{array}{l}\text { Tris-2-hydroxy ethyl isocyanurate, } \\
\text { hydroxyl groups }\end{array}$ & Anticorrosive & [143] \\
\hline
\end{tabular}


Table 3. Cont.

\begin{tabular}{|c|c|c|c|c|}
\hline NEVOs & Synthetic Intermediate/Pathway & Functional Ingredients & Functionality & References \\
\hline $\mathrm{ABO}$ & PEtA & Fatty amide & Anticorrosive & [144] \\
\hline \multirow{2}{*}{$\mathrm{TO}$} & Hydroxylation, alcoholysis & Anhydrides, boric acid & Anticorrosive & [98] \\
\hline & Diels-Alder & Glycidyl methacrylate & Anticorrosive & [145] \\
\hline \multirow{4}{*}{$\mathrm{MO}$} & Fatty amide & Fatty amide, diethanolamine & $\begin{array}{l}\text { Anticorrosive, } \\
\text { Antibacterial }\end{array}$ & [146] \\
\hline & PEtA & \multirow{3}{*}{$\begin{array}{c}\text { Fatty amide } \\
\text { Fatty amide, diglycidyl ether of } \\
\text { bisphenol-A } \\
\text { Fatty amide, Bisphenol-C }\end{array}$} & Anticorrosive & [35] \\
\hline & PEtA & & Antibacterial & [147] \\
\hline & PEtA & & Antibacterial & [148] \\
\hline TPO & PEsA, glycerides & Fatty amide, $\mathrm{ZnO}$ NPs & Anticorrosive & {$[149,150]$} \\
\hline \multirow{3}{*}{ Cardanol } & Epoxidation, hydroxylation & - & Anticorrosive & [151] \\
\hline & Epoxidation, hydroxylation & - & Anticorrosive & [152] \\
\hline & Cardanol-epoxy condensation & Autoxidative catalyst drier & Anticorrosive & [93] \\
\hline \multirow{3}{*}{$\mathrm{JO}$} & PEtA & Fatty amide, hydroquinone & Anticorrosive & [153] \\
\hline & PEsA & Fatty amide, itaconic acid & Anticorrosive & [46] \\
\hline & PEsA & Fatty amide, fumed silica NPs & Anticorrosive & [154] \\
\hline
\end{tabular}

\subsection{Nonedible Vegetable Oil-Based Anticorrosive Polyurethane Coatings}

\subsubsection{Anticorrosive Polyurethane Coatings: Adhesion}

Corrosion is considered a metallic cancer. It is a natural phenomenon causing deterioration of metal through chemical/electrochemical reaction with environment. Corrosion cannot be completely eradicated, but can be overcome in a number of ways, such as cleaning the environment, alloying metals, using inhibitors, using paints and coatings, etc. Among these methods, the use of polymeric coatings is widely accepted since they are easier to apply and cheaper than other methods. These provide protection against environmental attack on metals for quite a long time [114,155].

Corrosion processes on metallic surfaces involve conversion of metal atoms into an ionic state through oxidation reaction. Due to the electro-neutrality principle, electrons released from the metal atom need to be taken up by some oxidizing agent. Water contains dissolved atmospheric oxygen, which readily serves the purpose of electron acceptor and is electrochemically reduced to hydroxyl ions. The metal ions and hydroxyl ions combine together to produce metal hydroxide, which further reacts with more oxygen to form hydrated metal oxide (i.e., corrosion, Figure 8a) [120].

Therefore, prohibiting the permeation of corrosive media is a basic requirement for anticorrosive performances. Uniform and well-adhered PU coating over the metal substrate due to the presence of heteroatoms in its chemical structure, such as oxygen and nitrogen in urethane linkages, thus make it an inherently excellent anticorrosive coating material. The many lone pairs of electrons on the heteroatoms interact with the vacant d-orbital of metal to form coordination bonds $[63,156]$. The protection mechanism is simply through the barrier action attributed to the well-adhered PU coating [120].

For an even stronger affinity with the metal surface, researchers have tried to incorporate heterocyclic or aliphatic heterocompounds with additional heteroatoms, such as nitrogen, sulfur, and oxygen atoms, into PUs. The proposed interaction mechanism of the heteroatoms with a metal substrate is demonstrated in Figure 9. Nitrogen, sulfur, and oxygen atoms contain a lone pair of electrons that can bond with metal substrates to form coordination bridges. Such strong adhesion does not allow corrosive ions to penetrate the metal surface $[63,120]$. 


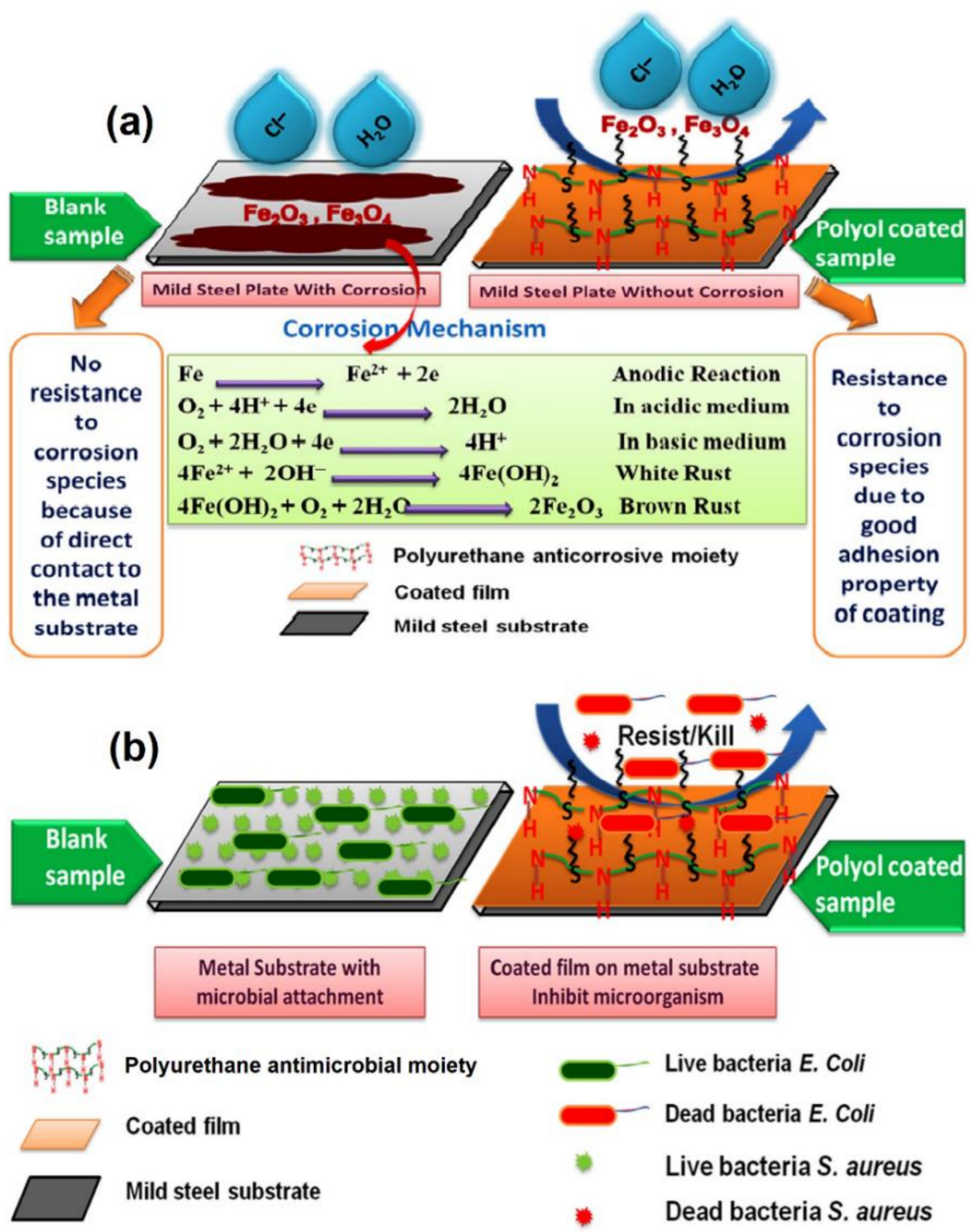

Figure 8. Proposed mechanisms of the anticorrosive (a) and antimicrobial (b) performances of PU coatings. This image is reproduced from reference [103] with permission. Copyright of the Reactive and Functional Polymers (Elsevier).

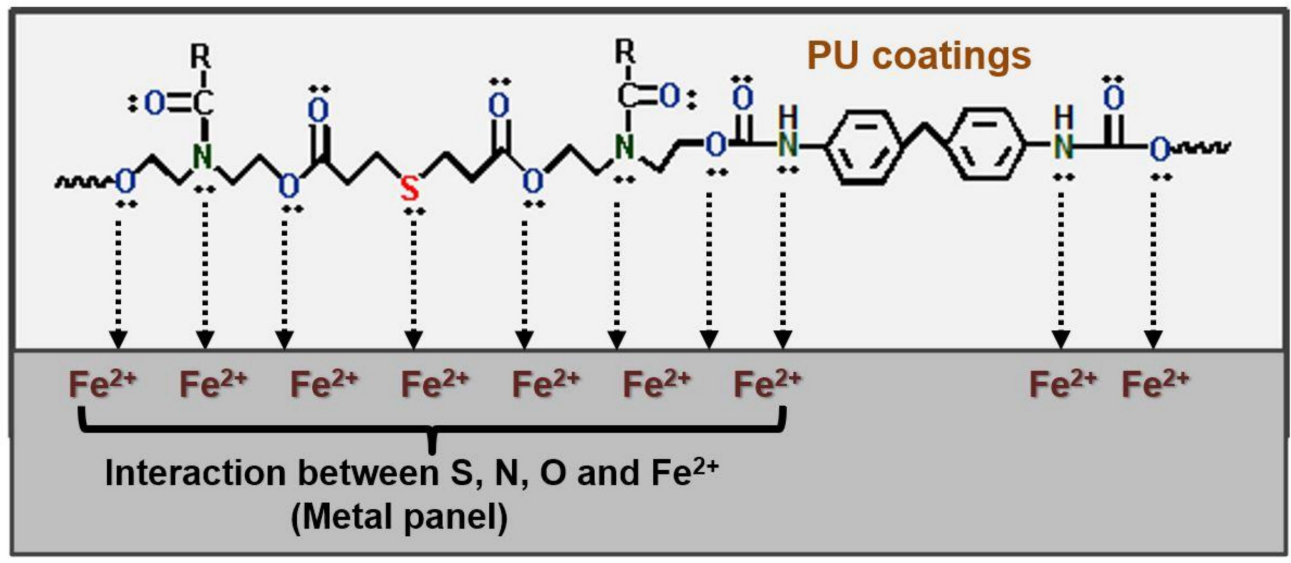

Figure 9. Possible interactions of heteroatoms of PU coatings with Fe (metal substrate). 
Corrosion inhibitors containing sulfur atoms, such as mercaptosuccinic acid and thiodipropionic acid, were used for the development of anticorrosive PU coatings from AO. The AO-based coatings showed a good barrier property against $\mathrm{NaCl}$ and $\mathrm{HCl}$ corrosive media. The anticorrosion activity of these coatings is mainly attributed to the excellent adhesion and strong interactions between the sulfur of mercaptosuccinic acid and thiodipropionic acid with a metal substrate [103]. The projected anticorrosion reaction mechanism and Tafel plots are shown in Figures 8 and 10, respectively. Researchers also utilized bis(4-aminophenyl)sulfone [139,140], pyridine [63], piperazine [120], and 1-thioglycerol/orthophosphoric acid [157] as corrosion inhibitors.
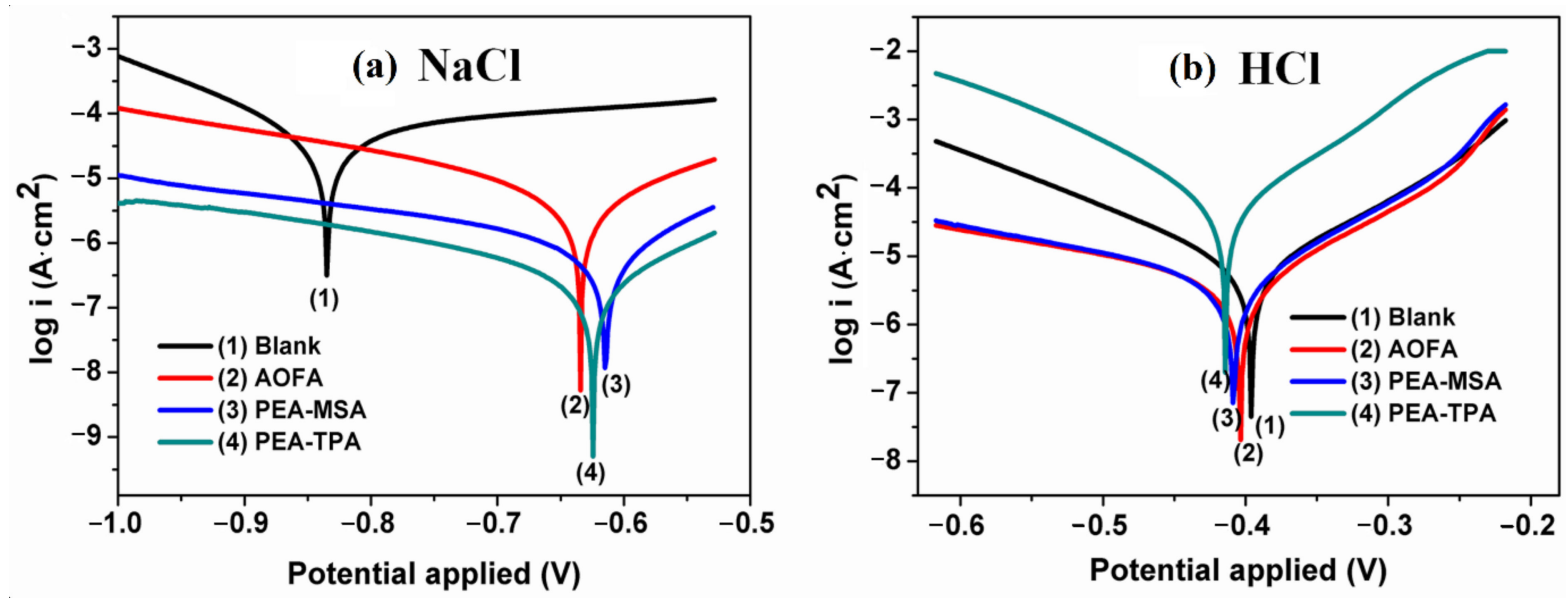

Figure 10. Tafel plots of electrochemical corrosion studied by PDP of uncoated (blank) and PU coated MS panels in $3.5 \%$ $\mathrm{NaCl}(\mathbf{a})$ and $0.5 \mathrm{M} \mathrm{HCl}(\mathbf{b})$ solutions. This image is reproduced from reference [103] with permission. Copyright of the Reactive and Functional Polymers (Elsevier).

LO-based cyclocarbonate precursors for nonisocyanate PU coatings were reported by Pouladi et al., through the epoxidation and carbonation of $\mathrm{LO}$, followed by a reaction with diethylenetriamine [109]. CO-based nonisocyanate PU coating was also reported by Sabnis et al. [143]. Hydroxyl groups produced by the reaction between cyclocarbonate and amines provided excellent adhesion to the substrate.

PU coatings based on alkyd resins of NO were prepared by the monoglyceride route, and they exhibited good flexibility and high gloss due to the high content of oil and long fatty acid chain of the prepared polyol [121]. KO-based polyols were also prepared through epoxidation and esterification, in which KO-based PU coatings exhibited good thermal and physicomechanical properties [23].

Fatty amide is another candidate that provides not only improved physicochemical properties but also better anticorrosive performances of PUs. Fatty amide contains an additional nitrogen atom in its chemical structure, improving its adhesion and anticorrosive characteristics. Poly(urethane fatty amide) (PUFA) showed better coating performance in terms of gloss, bending, chemical resistance, impact resistance, scratch resistance, and thermal resistance. Ahmad et al., reported LO-based PUFA composite with conducting polymer, poly(1-naphthylamine) [113]. The dense and continuous structure of the tested coatings was consistent with their ability to protect the metal substrate from corrosion. The PUFA matrix functioned as a barrier coating and prevented the penetration of aggressive ions, while the conducting polymer reacted with the substrate to form a passive oxide layer [113]. NO fatty amide-based PU coatings showed good anticorrosive performance due to the excellent adhesion of the coatings with a metal substrate [119]. The LO-based one-pack PUFA resin was reported by Ahmad et al., including amidation of LO with diethanolamine followed by a reaction with TDI [65]. Gite et al. reported NO-based PU coatings using a trimer of isophorone diisocyanate and fatty amide polyol [119]. Karak et al. reported poly(urethane amide) coating resins from purified NAO and TDI [75]. General 
coating performances of the resins were better than those of corresponding polyester or PEsA coatings, exhibiting good chemical resistance in various test media.

PEsA polyols have been developed by the reaction of NEVO fatty amides with diacids to improve the properties of coatings, such as corrosion resistance, thermal properties, and physicomechanical properties [62]. Gite et al. prepared AO-based PEsA polyols using different diacids and utilized them for the development of anticorrosive and antimicrobial PU coatings $[26,103,104]$. LO-based PEsA polyols have been developed by the reaction of LO fatty amides with ethylenediaminetetraacetic acid (EDTA) [62]. PU coatings prepared from pyridine dicarboxylic acid-LO PEsA polyols showed good corrosion resistance [63]. PEsA polyols have been developed by the reaction of $\mathrm{LO}, \mathrm{PO}$, and CO-based fatty amides with itaconic acids to improve the properties of coatings [111]. The PEsA-based PU coatings have fatty amide groups and polar urethanes linkages, forming $\mathrm{H}$ bonds with the metal substrates and enhancing their adhesion performance.

Alam et al. designed an anticorrosive PEsA polyol by replacing typical dicarboxylic acids with EDTA [62], ethylene glycol tetraacetic acid [124], and itaconic acid/trans-1,2diaminocyclohexane- $\mathrm{N}, \mathrm{N}, \mathrm{N}^{\prime}, \mathrm{N}^{\prime}$,-tetraacetic acid $[46,154]$, employing $\mathrm{LO}, \mathrm{PO}$, and JO, respectively. The PU coatings prepared from EDTA and trans-1,2-diaminocyclohexane$\mathrm{N}, \mathrm{N}, \mathrm{N}^{\prime}, \mathrm{N}^{\prime}$-tetraacetic acid-based polyols have a combination of amine groups, ester groups, urethane groups, and pendant alkyl chains. JO-derived poly(esteramide urethane)/fumed silica nanocomposite PU coatings were demonstrated by Alam et al., which showed good adhesion, hardness, gloss, and anticorrosive properties [154]. NO-based PEsA polyols were also prepared for self-healing anticorrosive PU coatings, where polyamidoamine-based polyurea microcapsules were filled with LO [28].

Despite their many advantages, PEsA coatings possess some drawbacks, such as poor alkali resistance and low thermal stability. Therefore, to achieve good performance, researchers have moved toward a new class of intermediates, such as PEtA, which exhibits good mechanical and chemical properties.

PU prepared from AO-based PEtA polyols showed good anticorrosive capability due to the nitrogen containing polyols with long aliphatic chain of AO [50]. Alam et al. reported the use of $\mathrm{LO}$ for the preparation of PEtA resins using bisphenol-A and resorcinol, affording improved mechanical properties, such as scratch hardness, impact resistance, and bending resistance [64]. Shaik et al. also reported the use of $\mathrm{LO}$ for the preparation of PEtA resins in the presence of $\mathrm{Fe}_{2} \mathrm{O}_{3}$ NPs as a corrosion inhibitor [112]. Further example of PU coatings with additional heteroatoms includes a polyol developed from PO and ethane-1,2-di(azomethine) bisphenol (hydroxyl terminated Schiff base) [125]. The polyol showed improved anticorrosive properties due to the presence of imine groups.

Akintayo et al. prepared PEtA polyol-based coatings from ABO and bisphenol-A with different loadings of TDI [144]. The prepared coatings achieved good flexibility, adhesion, scratch hardness properties, and impact resistance with increased loading of TDI (10-20\% TDI loading). These observed results may be due to the presence of polar urethane, amide, ether groups and fatty acid chains, which form bonds with the substrate [144]. A MO-modified PEtA polyol-based PU was reported and exhibited good anticorrosion performance against acid and salt solutions [35]. Yemul et al. converted MO into PEtA polyol using bisphenol-A, which was reacted with methylene diphenyl diisocyanate/TDI and resulted in good coating properties [35]. JO-based PEtA for PU coatings were presented by Alam et al. [153].

\subsubsection{Anticorrosive Polyurethane Coatings: Crosslinking}

A review of various PUs elucidated the influence of the crosslinking on the properties of the PUs due to the formation of the three-dimensional network. The crosslinked structure reduces the void space, pores, and free volume in the coating structure, making the path for the penetration of the corrosive electrolyte more tortuous [123]. Ahmad et al. delivered a pioneering work on PU coatings prepared from LO by epoxidation and hydroxylation, showing good anticorrosive properties due to their highly crosslinked struc- 
ture [105]. Gite et al. compared the anticorrosive properties of NO-based alkyd-modified PU coatings by using an immersion method, exhibiting better anticorrosive nature due to increased crosslinking reaction [121]. Ranade et al. explored the integration of PO for better crosslinking of PU coating, inhibiting electrolyte mass flow through the coating [123]. Gite et al. showed that the combination of $\mathrm{CO}$ monoglycerides and IPDI trimer forms better crosslinked PUs, exhibiting good resistance towards acids, alkalis and solvents [129]. Siyanbola et al., introduced poly(epichlorohydrin-triol) crosslinker to CO-based PU coatings. The improved crosslinking and adhesion on mild steel gave a better chemical resistance [132]. Recently, Benedetti et al. claimed improved corrosion protection of aluminum alloy AA2024 by tannin-modified CO-based PU coating, which favor crosslinking due to a high number of -OH groups in the chemical structure [136,137].

Yang et al. demonstrated the Diels-Alder reaction of TO and acrylates for potential ultraviolet-curable nonisocyanate PU coatings [145]. Epoxy resin was synthesized from cardanol oil and further utilized for the preparation of PU coatings $[93,151]$. The corrosion resistance showed improvement in barrier properties by oxidative crosslinking [93]. Sabnis et al., also prepared PU coatings by the reaction of cadanol-based diglycidyl ether with various multifunctional acids [152]. The crosslinking densities of cured coatings were observed to have great impact on chemical resistance, thermal stability and anticorrosive performance of prepared PU coatings.

Hyperbranched PU is not a crosslinked polymer network, but it has received considerable attention due to its unusual chain architectures and characteristics, such as high solubility, low hydrodynamic diameter, low melting temperature and solution viscosity [158]. Hyperbranched urethane alkyd coatings were prepared from LO and isocyanate trimer by Naik et al., showing excellent mechanical and corrosion resistance properties [116]. Karak et al. reported that the monoglyceride $\mathrm{CO}$ is an effective intermediate for the preparation of hyperbranched PU, exhibiting good resistance under various chemical environments due to the presence of high hydrophobic part [32].

\subsubsection{Anticorrosive Polyurethane Coatings: Organic-Inorganic Hybrids}

The combinations of organic with inorganic compounds have been studied to fulfill the necessities of PU coatings with specific properties such as anticorrosive performances. The corrosion protection mechanism of inorganic filler can be explained based on the formation of impermeable barrier phase at the interface of corrosive media and the metal substrate, which prohibits the permeation of electrolyte ions through coatings [114].

The siloxane/urethane hybrid exhibits good anticorrosive performances. PU coatings were prepared from epoxidized $\mathrm{CO}$ with different proportions of metallic inorganic/organic agents such as titanium isopropoxide with 3-aminopropyltriethoxysilane or tetraethoxyorthosilicate (TEOS), exhibiting improved anticorrosion/barrier characteristics due to $\mathrm{Si}-\mathrm{O}-\mathrm{Si}$ linkages, which provides excellent adhesion and hydrophobic property to the hybrid PU films [159]. Similarly, silica containing hybrid PUFA coatings were prepared through the reaction of LO fatty amide and TEOS [114]. The corrosion resistance of the PU coatings was increased with increasing loading of TEOS, again due to the presence of $\mathrm{O}-\mathrm{Si}-\mathrm{O}$ hydrophobic groups. The coating prevented the penetrations of corrosive ions of alkaline $\mathrm{NaOH}$ medium, whereas it failed to protect the substrate against acidic medium because of the breakdown of amide bond of PUFAS [114]. Shaik et al. prepared a hybrid PU by acrylated alkoxy silane polyol through radical copolymerization, which is synthesized from 3-(trimethoxysilyl)propyl methacrylate and CO [128]. Raju et al. reported silica (3-aminopropyltrimethoxysilane)/ZnO hybrid PU coatings from TPO [149].

Alumina can also be incorporated into PU framework to enhance physicomechanical and anticorrosion characteristics [110]. The performances of alumina-filled PEsA urethane coatings were much better than those of corresponding PEsA urethane coatings. Benedetti et al. also prepared PU coatings with inorganic corrosion inhibitor, zinc flake, using polyester polyol and the CO-based prepolymer on the aluminum alloy [135]. 
Protective and reinforced one coating systems for steel were prepared from PU and red iron oxide pigments as an anticorrosive filler by Morsi et al. [133]. CO-based PU acted as a binder in the formulation with red iron oxide pigments, where the long aliphatic chains of $\mathrm{CO}$ played an important role in higher protection activity.

Of late, boron has been adopted in the backbone of polymers to develop semi-inorganic polymers $[134,160]$. Anticorrosive performance of PU coatings containing boron with LO, PO, and TO-based polyols were also reported $[98,107,126]$. In these formulations, boron played the roles of crosslinker and modifier, which increased number of -O-B-O- linkage to improve the anticorrosion characteristics [107].

\subsubsection{Anticorrosive Polyurethane Coatings with Additives: Nanocomposites}

In recent decades, researchers have successfully synthesized polymeric resins with nanoparticles (NPs) for various applications. These resins with NPs have shown good coating characteristics and thermal stabilities. Nanocomposites are thus an emerging class of materials used to develop coatings, which may offer significant barrier properties for corrosion protection. In this context, incorporation of NPs in NEVO-based PU has been a potential way to improve the anticorrosion performances of the coatings [27,161]. These coatings exhibited enhanced anticorrosion performances by blocking the vulnerable sites of steel panels with the nanofillers.

Various nanofillers, such as fumed silica, $\mathrm{TiO}_{2}, \mathrm{ZnO}$, and $\mathrm{Fe}_{2} \mathrm{O}_{3} \mathrm{NPs}$, have been reported in NEVO-based polyols and PUs [112,118,149,150,154]. PU with silver (Ag)-doped hydroxyapatite (HAP) NPs and the PEsA polyol were prepared from AO and ricinoleic acid, exhibiting anticorrosion characteristics (Table 4, Figure 11) [104]. The improved anticorrosion characteristics were attributed to the nonporous, hydrophobic nature of the coating and the presence of hydrolytically stable urethane bonds, which provided better adhesion of the coatings to the substrate.

Table 4. Electrochemical corrosion study of uncoated (blank), PU-coated mild steel (0\% Ag-HAP) and PU with Ag-HAP NPs in a $3.5 \mathrm{wt} \% \mathrm{NaCl}$ corrosive solution. This table is reproduced from reference [104] with permission. Copyright of the Progress in Organic Coatings (Elsevier).

\begin{tabular}{cccccc}
\hline $\begin{array}{c}\text { Ag-HAP } \\
\text { Content }\end{array}$ & $\begin{array}{c}\mathbf{E}_{\text {corr }} \\
(\mathbf{m V})\end{array}$ & $\begin{array}{c}\mathbf{I}_{\mathbf{c o r r}} \\
\left(\boldsymbol{\mu} \mathbf{A ~ c m} \mathbf{~ c m}^{-2}\right)\end{array}$ & $\begin{array}{c}\mathbf{R}_{\mathbf{p}} \\
(\mathbf{k} \boldsymbol{\Omega})\end{array}$ & $\begin{array}{c}\text { Corrosion Rate } \\
(\mathbf{m m} / \text { Year) }\end{array}$ & $\begin{array}{c}\text { Inhibition } \\
\text { Efficiency } \mathbf{( \% )}\end{array}$ \\
\hline Blank & -842.90 & 9.38130 & 1.7244 & 0.10901 & - \\
$0 \%$ & -600.450 & 0.0056990 & 57.0990 & 0.00662 & 99.39 \\
$0.5 \%$ & -563.080 & 0.0053659 & 38.3980 & 0.00623 & 99.94 \\
$1 \%$ & -459.450 & 0.0032487 & 81.4370 & 0.00377 & 99.96 \\
$2 \%$ & -591.100 & 0.0027605 & 85.4140 & 0.00320 & 99.97 \\
$4 \%$ & -517.430 & 0.0018696 & 128.700 & 0.00217 & 99.98 \\
\hline
\end{tabular}

Carbon nanofillers can be another option for anticorrosive PU coatings. Graphene oxide (GOx) nanofillers can be an example of the carbon nanofillers [122]. The prepared coatings restricted the formation of rust and bacterial growth on the metal surface and formed a barrier to aggressive species $\left(\mathrm{O}_{2}, \mathrm{H}_{2} \mathrm{O}\right.$, and $\left.\mathrm{Cl}^{-}\right)$. The results were attributed to the $\pi-\pi$ interactions of GOx and double bonds of fatty acid chains [122]. Siyanbola et al., developed CO-based PU with carbon nanorods [127]. The carboxylated carbon nanomaterials were synthesized from incinerated Eucalyptus globulus leaves, affording PU composites with improved hydrophobicity and anticorrosion properties. 

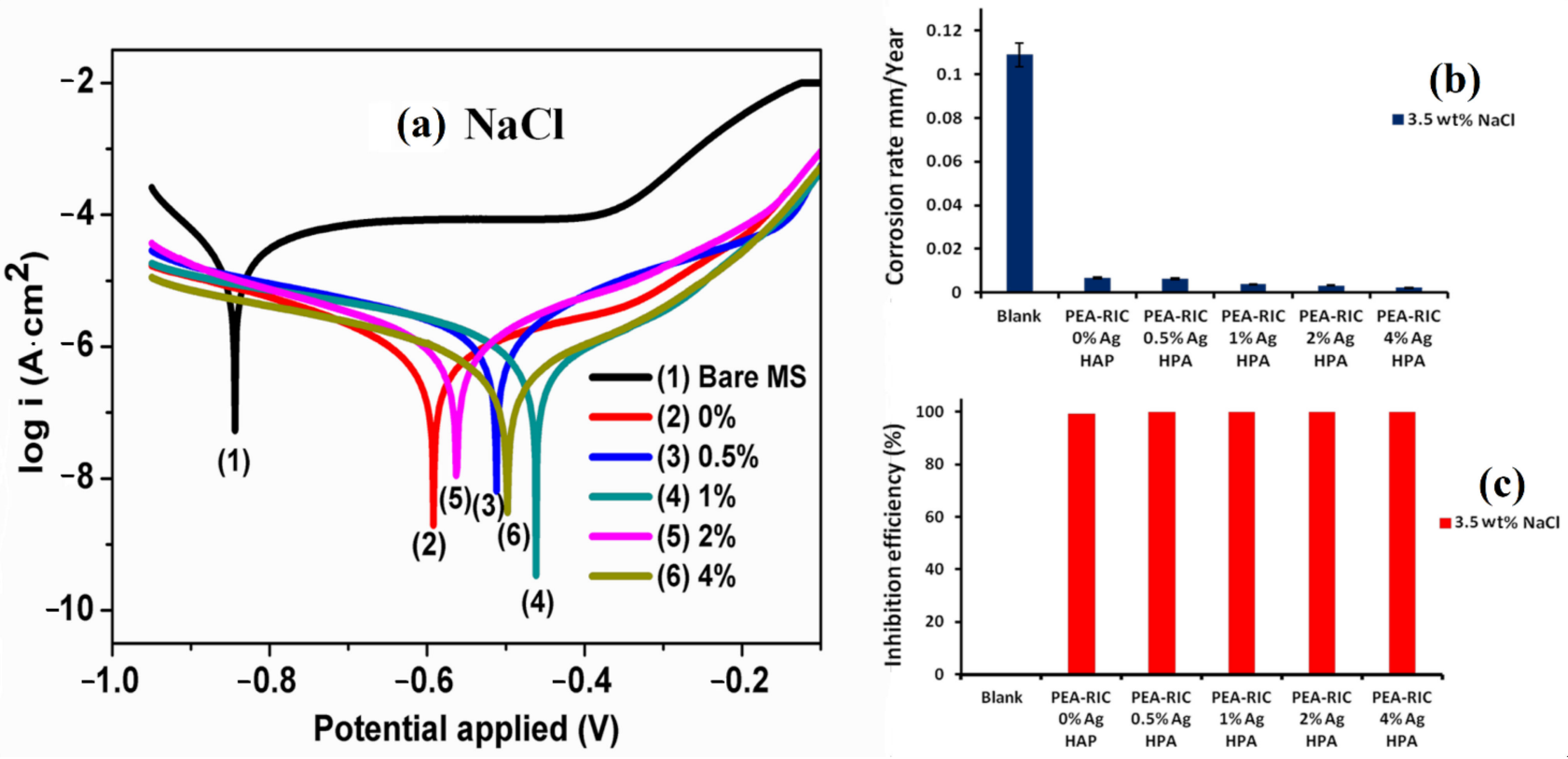

Figure 11. Tafel plots (a), corrosion rate (b), and inhibition efficiency (c) of PU coatings tested in a $3.5 \mathrm{wt} \% \mathrm{NaCl}$ solution with or without Ag-HAP NPs. This image was reproduced from reference [104] with permission. Copyright of the Progress in Organic Coatings (Elsevier).

\subsubsection{Anticorrosive Polyurethane Coatings with Additives: Microcapsules}

The preparation of smart anticorrosive PUs using renewable and ecofriendly resources has been a trendy research topic in recent years. One of the most versatile ways to prepare smart polymers is to use microcapsule-containing active ingredients, e.g., self-healing agents and corrosion inhibitors [162-164].

Microcapsules containing LO have autoxidative properties due to its drying characteristics, which repair minor cracks without manual intervention [165-167]. Self-healing anticorrosive PU coatings of LO-based microcapsules have been reported [28]. The coatings exhibited good anticorrosion performances in electrolyte solution due to the healing properties of LO [28].

Gite et al. reported the synthesis of acetylated polyester polyols from NO and converted them into anticorrosive PU coatings with the incorporation of encapsulated quinoline microcapsules as a corrosion inhibitor [117]. The coatings slowly released a quinoline inhibitor from the microcapsules, protecting the substrate for an extended period (Figure 12) [117].

\subsection{Nonedible Vegetable Oil-Based Antimicrobial Polyurethane Coatings}

The global concerns about the risk of bacterial infection have been growing over the past decades [168]. In this regard, coatings with antibacterial activity have offered an approach to limit the spread of bacterial infections in many areas such as medical devices, healthcare products, hospitals/dental office equipment, and food/drug manufacturing $[168,169]$.

The long hydrocarbon chains of fatty triester residues containing hydroxyl groups, carbamate groups, and isocyanate groups can elicit an inhibitory response. These active agents damage lipid complexes in cell membranes or dehydrate bacterial cells. The PUs prepared from the CO-based epoxy- and LO-based hydroxy-terminated polyol have cytocompatibility and antibacterial activity against $S$. aureus and E. coli, which allow them to be used in wound dressing applications $[106,115,170]$. CO has good compatibility with polycaprolactone and improved the antibacterial performance of PU coatings [138]. Antibacterial PU coatings produced from epoxidized LO and PO-based polyol were also tested against E. coli [106], and the bioflavonoids karanjin and pongamol played an important role 
in the performance of the coatings [171]. MO-based PUFA also exhibited good antibacterial activities [146-148].

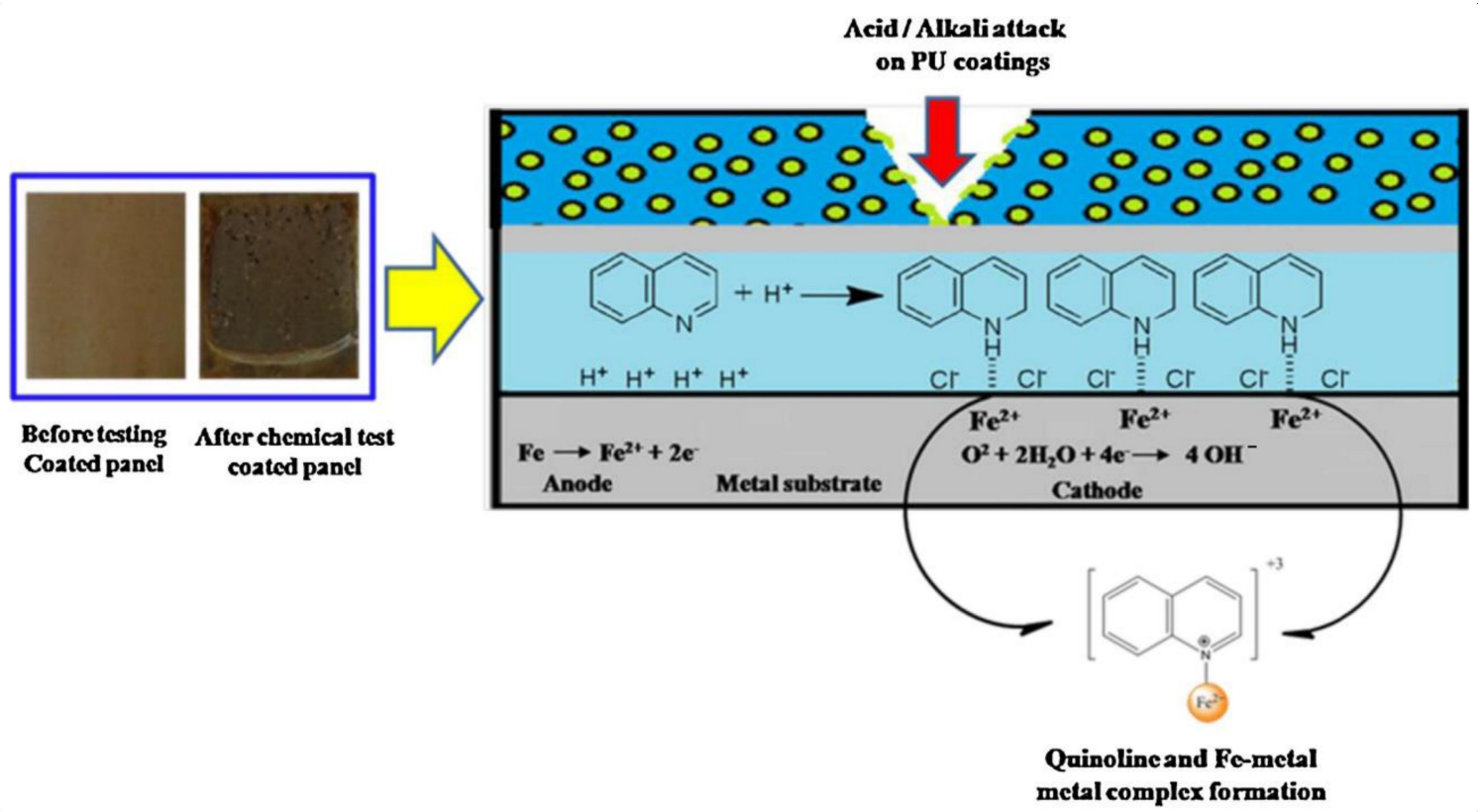

Figure 12. Possible corrosion inhibition and complex formation mechanism of encapsulated quinoline-loaded NAPP-MDI coatings on Fe-metal. This image is reproduced from reference [117] with permission. Copyright of the Industrial Crops and Products (Elsevier).

Different agents can be incorporated into the formulation of PU coatings to provide better antibacterial activity [131]. Quaternary ammonium salts showed broad spectrum antibacterial activity against both Gram-positive and Gram-negative bacteria and a high inhibition rate over a wide range of $\mathrm{pH}$ values. PU containing covalently bonded quaternary ammonium salts showed good antibacterial performance [131].

Metallohybrid PU composite coatings were developed from copper acetate and LObased polyol [108,172], which showed notable antibacterial performance against both $E$. coli and S. aureus. Parent oil, copper acetate, and $\mathrm{CuO}$ bound to lipids in the bacterial cell wall, which disrupted the integrity of the cytoplasmic membrane and blocked the entry of essential nutrients into cells.

Antimicrobial PU coatings were also prepared from $\mathrm{Zn}$ - and Cd-incorporated LObased poly(esteramide-urethane), exhibiting superior performance to previously reported systems [57,172,173]. Moreover, PU nanocomposite coatings obtained from TPO polyols and siloxane-modified $\mathrm{ZnO}$ showed antibacterial performance towards E. coli and S. aureus [149]. Self-healable CO-based hyperbranched PU coatings modified with sulfur NPs and reduced GOx showed good microbial inhibition against both bacteria (S. aureus and $E$. coli) and fungi (C. albicans) [174], as evidenced by the membrane disruption and irregularity of the cellular structures.

$\mathrm{Ag}$ has long been known for its good antimicrobial efficiency and hence has been utilized in many polymer composites. HAP NPs are another example that can be prepared from biowaste materials, i.e., waste egg shells. Gite et al. developed antibacterial PU coatings by employing PEsA, PEtA, Ag-doped eggshell HAP, and thio-diacids [26,50,103,104]. The prepared PU coatings showed good antibacterial potential against Gram-positive and Gram-negative bacteria due to the presence of a high percentage of oleic acid in $\mathrm{AO}$, which can inhibit bacterial growth [175]. The observations of ruptured surfaces and decreased bacterial growth on PU-coated surfaces were confirmed by SEM analysis, as shown in Figure 13. The penetration effect of Ag NPs into the surface of the cell membrane can disturb the permeability and respiration functions of the cell $[176,177]$. CO-based waterborne 
antibacterial PU nanocomposites were prepared by incorporating Ag-halloysite composites, catalyzing the production of oxygen radicals to inhibit the growth of microorganisms [178].
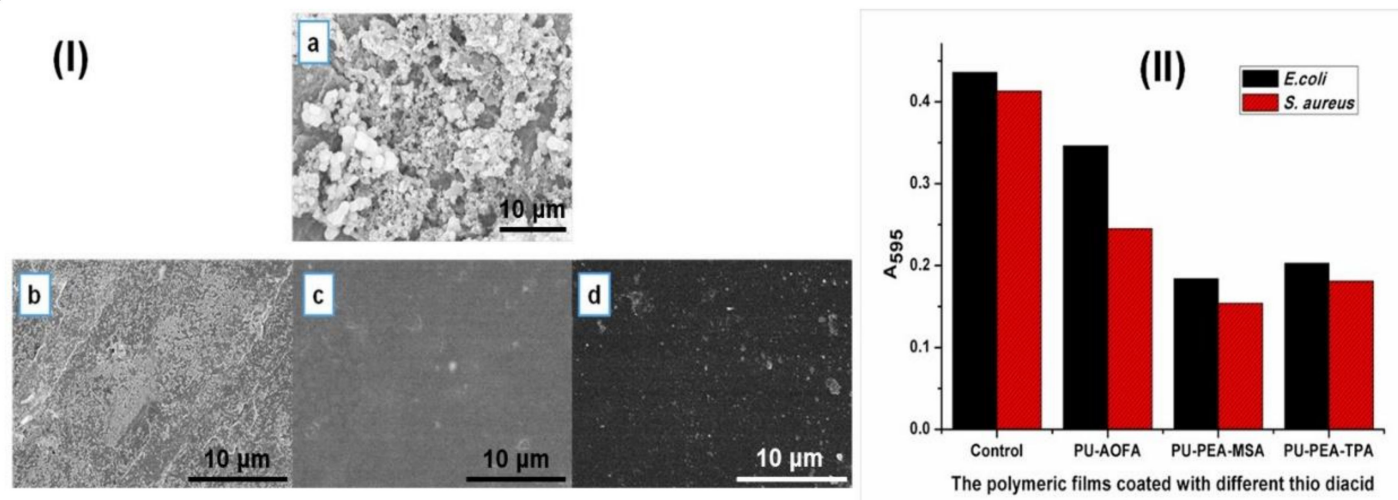

(III)
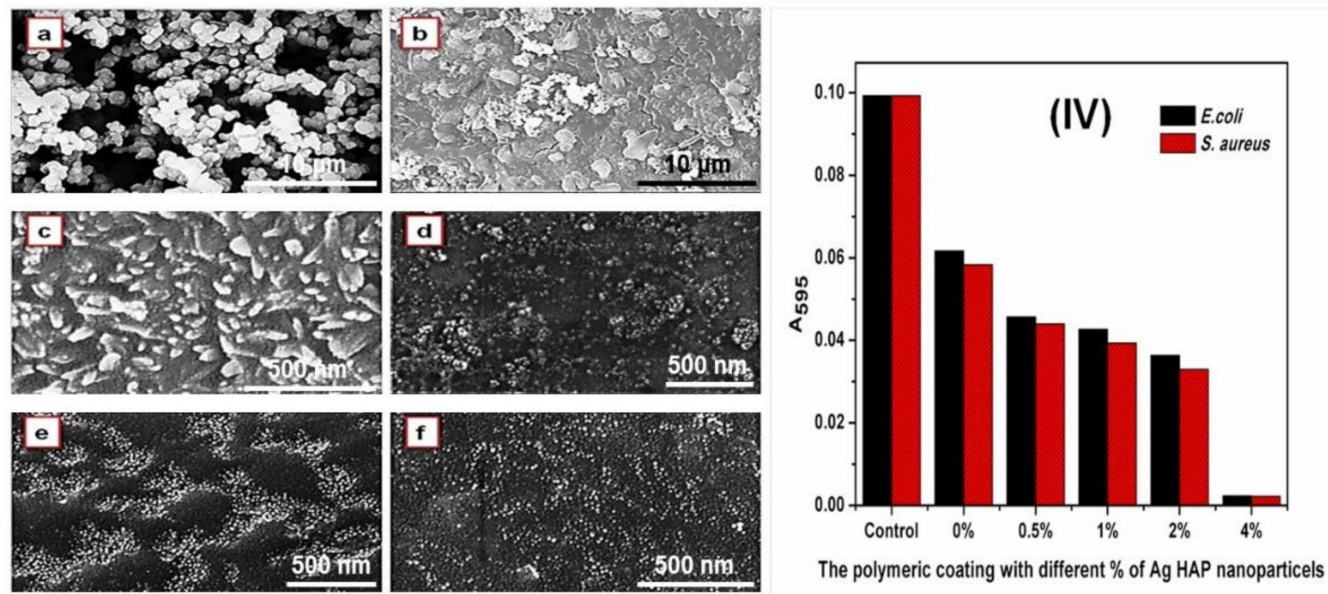

Figure 13. SEM images of PU coatings tested against E. coli and S. aureus containing PEsA- mercaptosuccinic acid/PEsAthiodipropionic acid (I; a, uncoated metal tray; b, PU coating with algae oil fatty amide; c, PU coating with PEsAmercaptosuccinic acid; d, PU coating with PEsA-thiodipropionic acid) and Ag-HAP NPs (III; a, MS panel; b, PU coating without Ag-HAP; c, PU coating with 0.5\% Ag HAP NPs; d, 1\% Ag HAP NPs; e, 2\% Ag HAP NPs; f, 4\% Ag HAP NPs). Graphical representations of uncoated and coated MS panels tested against E. coli and S. aureus containing mercaptosuccinic acid/thiodipropionic acid (II) and Ag-HPA NPs (IV): Absorbance at $595 \mathrm{~nm}$ as a measure of cell growth. These images are reproduced from references $[103,104]$ with permission. Copyright of the Reactive and Functional Polymers and Progress in Organic Coatings (Elsevier).

$\mathrm{TiO}_{2}$ NPs exhibited good antimicrobial activity and strongly bonded to electron donor groups in biological molecules containing oxygen, nitrogen, and sulfur, which destroyed the outermost layer of microorganisms [141]. $\mathrm{TiO}_{2}$ incorporated CO-based $\mathrm{PU}$ nanocomposites and waterborne PU dispersions showed good antibacterial and antifungal activities against S. aureus, E. coli, B. pasteurii, Vibrio parahaemolyticus, and other fungal species [179].

Hybrid PU coatings with CO/LO-based PU with TEOS exhibited good antibacterial behavior against E. coli and S. aureus due to the large surface area of silica NPs [142]. A PU hybrid containing 3-amino propyl trimethoxy silane and 3-glycidoxy propyl trimethoxy silane showed mild biocidal inhibition properties against bacteria E. coli and S. aureus due to the synergetic effect of hydroxyl, urethane, and Si components in the prepared PU film, which are responsible for breaking down bacterial proteins and restricting the cellular activity [130].

\section{Conclusions}

The most popular renewable precursor for the synthesis of biopolyols is vegetable oil. The selection of raw materials plays a substantial role in the preparation of polyols 
for the development of ecofriendly polyurethanes. Although several factors affect the selection process, such as productivity, viability, cost, environmental effects, conversion efficiency, reusability, and the presence of modification sites, nonedible vegetable oils are an excellent platform due to their nonedible nature. Several chemical pathways have been demonstrated to convert nonedible vegetable oils into polyols. The mechanical, chemical, thermal, anticorrosive, and antimicrobial characteristics of the nonedible vegetable oil-based polyols can be improved by advanced chemical modification strategies. New nonedible vegetable oils with additional functionalities and active ingredients can be good options for further applications of these materials, as demonstrated by the incorporation of nanofillers, silica, silver, hydroxyapatite, and inorganic metalloids. The use of microcapsules, triazines, thiocompounds, hybrids, and inhibitors has also been highlighted in this review. The preferred coatings have great potential in the field of high-performance, smart, and functional applications, including biomedical fields.

Author Contributions: Conceptualization, C.K.P., V.V.G. and S.C.H.; Investigation, C.K.P., D.W.J., H.D.J. and S.C.H.; Original draft preparation, C.K.P.; Writing-Review \& Editing, D.W.J., J.H.B., V.V.G. and S.C.H.; Resources, H.D.J.; Funding acquisition, J.H.B.; Supervision, V.V.G. and S.C.H. All authors have read and agreed to the published version of the manuscript.

Funding: This work was supported by the National Research Foundation of Korea (NRF) grant funded by the Korea government [NRF-2019R1A2C1003735 and NRF-2020R1A6A1A03043435]. This work was also supported by Korea Institute of Energy Technology Evaluation and Planning (KETEP) grant funded by the Korea government [MOTIE, 20208401010080]. Authors thank to the financial support of University Grants Commission (UGC) of New Delhi, India, for providing BSR-RFSMS fellowship to Chandrashekhar K. Patil.

Conflicts of Interest: The authors declare that they have no known competing financial interests or personal relationships that could have appeared to influence the work reported in this paper.

\section{Abbreviations}

$\begin{array}{ll}\text { ABO } & \text { Albizia benth seed oil } \\ \text { Ag } & \text { silver } \\ \text { AO } & \text { algae oil } \\ \text { CO } & \text { castor oil } \\ \text { EDTA } & \text { ethylenediaminetetraacetic acid } \\ \text { GOx } & \text { graphene oxide } \\ \text { HAP } & \text { hydroxyapatite } \\ \text { JO } & \text { jatropha oil } \\ \text { KO } & \text { karanja oil } \\ \text { LO } & \text { linseed oil } \\ \text { MO } & \text { mahua oil } \\ \text { NAO } & \text { Nahar seed oil } \\ \text { NEVO } & \text { nonedible vegetable oil } \\ \text { NO } & \text { neem seed oil } \\ \text { NP } & \text { nanoparticle } \\ \text { PEsA } & \text { polyesteramide } \\ \text { PEtA } & \text { polyetheramide } \\ \text { PO } & \text { pongamia glabra seed oils } \\ \text { PU } & \text { polyurethane } \\ \text { PUFA } & \text { poly(urethane fatty amide) } \\ \text { TDI } & \text { toluene diisocyanate } \\ \text { TEOS } & \text { tetraethoxyorthosilicate } \\ \text { TO } & \text { tung oil } \\ \text { TPO } & \text { thevetia peruviana seed oil } \\ \text { VO } & \text { vegetable oil } \\ & \end{array}$




\section{References}

1. Petrović, Z.S. Polyurethanes from vegetable oils. Polym. Rev. 2008, 48, 109-155. [CrossRef]

2. Szycher, M. Szycher's Handbook of Polyurethanes, 2nd ed.; CRC Press: Boca Raton, FL, USA, 2012. [CrossRef]

3. Rokicki, G.; Parzuchowski, P.G.; Mazurek, M. Non-isocyanate polyurethanes: Synthesis, properties, and applications. Polym. Adv. Technol. 2015, 26, 707-761. [CrossRef]

4. Chattopadhyay, D.K.; Raju, K.V.S.N. Structural engineering of polyurethane coatings for high performance applications. Prog. Polym. Sci. 2007, 32, 352-418. [CrossRef]

5. Noreen, A.; Zia, K.M.; Zuber, M.; Tabasum, S.; Zahoor, A.F. Bio-based polyurethane: An efficient and environment friendly coating systems: A review. Prog. Org. Coat. 2016, 91, 25-32. [CrossRef]

6. Gite, V.; Rajput, S.D.; Yemul, O.S. Advances in polyurethane coating technologies. Chem. Wkly. 2012, 58, $201-208$.

7. Datta, J.; Kasprzyk, P. Thermoplastic polyurethanes derived from petrochemical or renewable resources: A comprehensive review. Polym. Eng. Sci. 2018, 58, E14-E35. [CrossRef]

8. Hojabri, L.; Kong, X.; Narine, S.S. Fatty acid-derived diisocyanate and biobased polyurethane produced from vegetable oil: Synthesis, polymerization, and characterization. Biomacromolecules 2009, 10, 884-891. [CrossRef] [PubMed]

9. Hojabri, L.; Kong, X.; Narine, S.S. Novel long chain unsaturated diisocyanate from fatty acid: Synthesis, characterization, and application in bio-based polyurethane. J. Polym. Sci. Part A Polym. Chem. 2010, 48, 3302-3310. [CrossRef]

10. Sunder, A.; Türk, H.; Haag, R.; Frey, H. Copolymers of glycidol and glycidyl ethers: Design of branched polyether polyols by combination of latent cyclic $\mathrm{AB}_{2}$ and ABR monomers. Macromolecules 2000, 33, 7682-7692. [CrossRef]

11. Herrmann, A.; Kaufmann, L.; Dey, P.; Haag, R.; Schedler, U. Bioorthogonal in situ hydrogels based on polyether polyols for new biosensor materials with high sensitivity. ACS Appl. Mater. Interfaces 2018, 10, 11382-11390. [CrossRef]

12. Sunder, A.; Mülhaupt, R.; Haag, R.; Frey, H. Hyperbranched polyether polyols: A modular approach to complex polymer architectures. Adv. Mater. 2000, 12, 235-239. [CrossRef]

13. Gallezot, P. Conversion of biomass to selected chemical products. Chem. Soc. Rev. 2012, 41, 1538-1558. [CrossRef]

14. Khanderay, J.C.; Gite, V.V. Fully biobased polyester polyols derived from renewable resources toward preparation of polyurethane and their application for coatings. J. Appl. Polym. Sci. 2019, 136, 47558. [CrossRef]

15. Gandini, A. The irruption of polymers from renewable resources on the scene of macromolecular science and technology. Green Chem. 2011, 13, 1061-1083. [CrossRef]

16. Meier, M.A.R.; Metzger, J.O.; Schubert, U.S. Plant oil renewable resources as green alternatives in polymer science. Chem. Soc. Rev. 2007, 36, 1788-1802. [CrossRef] [PubMed]

17. Anand, A.; Kulkarni, R.D.; Patil, C.K.; Gite, V.V. Utilization of renewable bio-based resources, viz. sorbitol, diol, and diacid, in the preparation of two pack PU anticorrosive coatings. RSC Adv. 2016, 6, 9843-9850. [CrossRef]

18. Donnelly, M.J.; Stanford, J.L.; Still, R.H. The conversion of polysaccharides into polyurethanes: A review. Carbohydr. Polym. 1991, 14, 221-240. [CrossRef]

19. Chowdhury, R.A.; Clarkson, C.M.; Shrestha, S.; El Awad Azrak, S.M.; Mavlan, M.; Youngblood, J.P. High-performance waterborne polyurethane coating based on a blocked isocyanate with cellulose nanocrystals (CNC) as the polyol. ACS Appl. Polym. Mater. 2019, 2, 385-393. [CrossRef]

20. Liang, Y.; Zhang, D.; Zhou, M.; Xia, Y.; Chen, X.; Oliver, S.; Shi, S.; Lei, L. Bio-based omniphobic polyurethane coating providing anti-smudge and anti-corrosion protection. Prog. Org. Coat. 2020, 148, 105844. [CrossRef]

21. Adekunle, K.F. A review of vegetable oil-based polymers: Synthesis and applications. Open J. Polym. Chem. 2015, 5, 34-40. [CrossRef]

22. Banković-Ilić, I.B.; Stamenković, O.S.; Veljković, V.B. Biodiesel production from non-edible plant oils. Renew. Sustain. Energy Rev. 2012, 16, 3621-3647. [CrossRef]

23. Gaikwad, M.S.; Gite, V.V.; Mahulikar, P.P.; Hundiwale, D.G.; Yemul, O.S. Eco-friendly polyurethane coatings from cottonseed and karanja oil. Prog. Org. Coat. 2015, 86, 164-172. [CrossRef]

24. Kumar, A.; Sharma, S. Potential non-edible oil resources as biodiesel feedstock: An Indian perspective. Renew. Sustain. Energy Rev. 2011, 15, 1791-1800. [CrossRef]

25. Sahoo, P.K.; Das, L.M.; Babu, M.K.G.; Naik, S.N. Biodiesel development from high acid value polanga seed oil and performance evaluation in a CI engine. Fuel 2007, 86, 448-454. [CrossRef]

26. Patil, C.K.; Jirimali, H.D.; Paradeshi, J.S.; Chaudhari, B.L.; Alagi, P.K.; Hong, S.C.; Gite, V.V. Synthesis of biobased polyols using algae oil for multifunctional polyurethane coatings. Green Mater. 2018, 6, 165-177. [CrossRef]

27. Díez-Pascual, A.M.; Díez-Vicente, A.L. Development of linseed oil- $\mathrm{TiO}_{2}$ green nanocomposites as antimicrobial coatings. J. Mater Chem. B 2015, 3, 4458-4471. [CrossRef] [PubMed]

28. Chaudhari, A.B.; Tatiya, P.D.; Hedaoo, R.K.; Kulkarni, R.D.; Gite, V.V. Polyurethane prepared from neem oil polyesteramides for self-healing anticorrosive coatings. Ind. Eng. Chem. Res. 2013, 52, 10189-10197. [CrossRef]

29. Karmee, S.K.; Mahesh, P.; Ravi, R.; Chadha, A. Kinetic study of the base-catalyzed transesterification of monoglycerides from Pongamia oil. J. Am. Oil Chem. Soc. 2004, 81, 425-430. [CrossRef]

30. Bora, M.M.; Deka, R.; Ahmed, N.; Kakati, D.K. Karanja (Millettia pinnata (L.) Panigrahi) seed oil as a renewable raw material for the synthesis of alkyd resin. Ind. Crop. Prod. 2014, 61, 106-114. [CrossRef] 
31. Das, G.; Karak, N. Epoxidized Mesua ferrea L. seed oil-based reactive diluent for BPA epoxy resin and their green nanocomposites. Prog. Org. Coat. 2009, 66, 59-64. [CrossRef]

32. Thakur, S.; Karak, N. Castor oil-based hyperbranched polyurethanes as advanced surface coating materials. Prog. Org. Coat. 2013, 76, 157-164. [CrossRef]

33. Akintayo, C.O.; Akintayo, E.T.; Azeez, M.A. Albizia benth oil maleinised polyesteramides: Synthesis, structure, and characteristics. ISRN Polym. Sci. 2012, 2012, 708520. [CrossRef]

34. Mosiewicki, M.A.; Casado, U.; Marcovich, N.E.; Aranguren, M.I. Polyurethanes from tung oil: Polymer characterization and composites. Polym. Eng. Sci. 2009, 49, 685-692. [CrossRef]

35. Pawar, M.S.; Kadam, A.S.; Yemul, O.S. Development of polyetheramide based corrosion protective polyurethane coating from mahua oil. Prog. Org. Coat. 2015, 89, 143-149. [CrossRef]

36. Bora, M.M.; Gogoi, P.; Deka, D.C.; Kakati, D.K. Synthesis and characterization of yellow oleander (Thevetia peruviana) seed oil-based alkyd resin. Ind. Crop. Prod. 2014, 52, 721-728. [CrossRef]

37. Ashraful, A.M.; Masjuki, H.H.; Kalam, M.A.; Rizwanul Fattah, I.M.; Imtenan, S.; Shahir, S.A.; Mobarak, H.M. Production and comparison of fuel properties, engine performance, and emission characteristics of biodiesel from various non-edible vegetable oils: A review. Energy Convers. Manag. 2014, 80, 202-228. [CrossRef]

38. Ahamad, S.; Naqvi, F.; Verma, K.L.; Yadav, S. Studies on a newly developed linseed oil-based alumina-filled polyesteramide anticorrosive coating. J. Appl. Polym. Sci. 1999, 72, 1679-1687. [CrossRef]

39. Dutta, N.; Karak, N.; Dolui, S.K. Synthesis and characterization of polyester resins based on nahar seed oil. Prog. Org. Coat. 2004, 49, 146-152. [CrossRef]

40. Saravari, O.; Praditvatanakit, S. Preparation and properties of urethane alkyd based on a castor oil/jatropha oil mixture. Prog. Org. Coat. 2013, 76, 698-704. [CrossRef]

41. Hlaing, N.N.; Oo, M.M. Manufacture of alkyd resin from castor oil. World Acad. Sci. Eng. Technol. 2008, 48, 155-161.

42. Samadzadeh, M.; Boura, S.H.; Peikari, M.; Ashrafi, A.; Kasiriha, M. Tung oil: An autonomous repairing agent for self-healing epoxy coatings. Prog. Org. Coat. 2011, 70, 383-387. [CrossRef]

43. Shaker, N.O.; Alian, N.A.; El-Sawy, M.M. Preparation, characterization and evaluation of jojoba seed oil-modified alkyd resins. Chem. Sin. 2012, 3, 1157-1162.

44. Bhatia, V.K.; Chaudhry, A.; Sivasankaran, G.A.; Bisht, R.P.S.; Kashyap, M. Modification of jojoba oil for lubricant formulations. J. Am. Oil Chem. Soc. 1990, 67, 1-7. [CrossRef]

45. Khanderay, J.C.; Gite, V.V. Vegetable oil-based polyurethane coatings: Recent developments in India. Green Mater. 2017, 5, 109-122. [CrossRef]

46. Alam, M.; Alandis, N.M. Microwave assisted synthesis of urethane modified polyesteramide coatings from jatropha seed oil. J. Polym. Environ. 2011, 19, 784-792. [CrossRef]

47. Aplin, P.J.; Eliseo, T. Ingestion of castor oil plant seeds. Med. J. Aust. 1997, 167, 260-261. [CrossRef]

48. Shaw, D.; Pearn, J. Oleander poisoning. Med. J. Aust. 1979, 2, 267-269. [CrossRef]

49. Azam, M.M.; Waris, A.; Nahar, N.M. Prospects and potential of fatty acid methyl esters of some non-traditional seed oils for use as biodiesel in India. Biomass Bioenergy 2005, 29, 293-302. [CrossRef]

50. Patil, C.K.; Jirimali, H.D.; Paradeshi, J.S.; Chaudhari, B.L.; Alagi, P.K.; Mahulikar, P.P.; Hong, S.C.; Gite, V.V. Chemical transformation of renewable algae oil to polyetheramide polyols for polyurethane coatings. Prog. Org. Coat. 2021, 151, 106084. [CrossRef]

51. Naik, S.N.; Goud, V.V.; Rout, P.K.; Dalai, A.K. Production of first and second generation biofuels: A comprehensive review. Renew. Sustain. Energy Rev. 2010, 14, 578-597. [CrossRef]

52. Klein, J.; Zikeli, S.; Claupein, W.; Gruber, S. Linseed (Linum usitatissimum) as an oil crop in organic farming: Abiotic impacts on seed ingredients and yield. Org. Agric. 2017, 7, 1-19. [CrossRef]

53. Čeh, B.; Štraus, S.; Hladnik, A.; Kušar, A. Impact of linseed variety, location and production year on seed yield, oil content and its composition. Agronomy 2020, 10, 1770. [CrossRef]

54. El-Hamidi, M.; Zaher, F.A. Production of vegetable oils in the world and in Egypt: An overview. Bull. Natl. Res. Cent. 2018, $42,19$. [CrossRef]

55. Zafar, F.; Sharmin, E.; Ashraf, S.M.; Ahmad, S. Studies on poly(styrene-co-maleic anhydride)-modified polyesteramide-based anticorrosive coatings synthesized from a sustainable resource. J. Appl. Polym. Sci. 2004, 92, 2538-2544. [CrossRef]

56. El-Wahab, H.A.; El-Fattah, M.A.; Ghazy, M.B.M. Synthesis and characterization of new modified anti-corrosive polyesteramide resins incorporated pyromellitimide ring for surface coating. Prog. Org. Coat. 2011, 72, 353-359. [CrossRef]

57. Zafar, F.; Ashraf, S.M.; Ahmad, S. Studies on zinc-containing linseed oil based polyesteramide. React. Funct. Polym. 2007, 67, 928-935. [CrossRef]

58. Alam, M.; Alandis, N.M. Development of ambient cured polyesteramide coatings from linseed oil: A sustainable resource. J. Polym. Environ. 2011, 19, 391-397. [CrossRef]

59. Pathan, S.; Ahmad, S. Synergistic effects of linseed oil based waterborne alkyd and 3-isocynatopropyl triethoxysilane: Highly transparent, mechanically robust, thermally stable, hydrophobic, anticorrosive coatings. ACS Sustain. Chem. Eng. 2016, 4, 3062-3075. [CrossRef] 
60. İşeri-Çağlar, D.; Baştürk, E.; Oktay, B.; Kahraman, M.V. Preparation and evaluation of linseed oil based alkyd paints. Prog. Org. Coat. 2014, 77, 81-86. [CrossRef]

61. Sharmin, E.; Rahman, O.u.; Zafar, F.; Akram, D.; Alam, M.; Ahmad, S. Linseed oil polyol/ZnO bionanocomposite towards mechanically robust, thermally stable, hydrophobic coatings: A novel synergistic approach utilising a sustainable resource. RSC Adv. 2015, 5, 47928-47944. [CrossRef]

62. Alam, M.; Ray, A.R.; Ahmad, S. Synthesis and characterization of poly(esteramide-urethane) from linseed oil as anticorrosive coatings. J. Appl. Polym. Sci. 2009, 114, 3268-3273. [CrossRef]

63. Alam, M.; Ashraf, S.M.; Ahmad, S. Pyridine-poly(urethane ester amide) coatings from linseed oil. J. Polym. Res. 2008, 15, 343-350. [CrossRef]

64. Alam, M.; Ashraf, S.M.; Ray, A.R.; Ahmad, S. Development of anticorrosive poly(ether-urethane) amide coatings from linseed oil: A sustainable resource. J. Polym. Environ. 2010, 18, 208-215. [CrossRef]

65. Yadav, S.; Zafar, F.; Hasnat, A.; Ahmad, S. Poly(urethane fatty amide) resin from linseed oil-A renewable resource. Prog. Org. Coat. 2009, 64, 27-32. [CrossRef]

66. Bagle, A.V.; Jadhav, R.S.; Gite, V.V.; Hundiwale, D.G.; Mahulikar, P.P. Controlled release study of phenol formaldehyde microcapsules containing neem oil as an insecticide. Int. J. Polym. Mater. 2013, 62, 421-425. [CrossRef]

67. Biswas, K.; Chattopadhyay, I.; Banerjee, R.K.; Bandyopadhyay, U. Biological activities and medicinal properties of neem (Azadirachta indica). Curr. Sci. 2002, 82, 1336-1345.

68. Barnwal, B.K.; Sharma, M.P. Prospects of biodiesel production from vegetable oils in India. Renew. Sustain. Energy Rev. 2005, 9 , 363-378. [CrossRef]

69. Nayan, N.K.; Kumar, S.; Singh, R.K. Production of the liquid fuel by thermal pyrolysis of neem seed. Fuel 2013, 103, 437-443. [CrossRef]

70. Vismaya; Sapna Eipeson, W.; Manjunatha, J.R.; Srinivas, P.; Sindhu Kanya, T.C. Extraction and recovery of karanjin: A value addition to karanja (Pongamia pinnata) seed oil. Ind. Crop. Prod. 2010, 32, 118-122. [CrossRef]

71. Khayoon, M.S.; Olutoye, M.A.; Hameed, B.H. Utilization of crude karanj (Pongamia pinnata) oil as a potential feedstock for the synthesis of fatty acid methyl esters. Bioresour. Technol. 2012, 111, 175-179. [CrossRef] [PubMed]

72. Goud, V.V.; Pradhan, N.C.; Patwardhan, A.V. Epoxidation of karanja (Pongamia glabra) oil by $\mathrm{H}_{2} \mathrm{O}_{2}$. J. Am. Oil Chem. Soc. 2006, 83, 635-640. [CrossRef]

73. Das, G.; Karak, N. Mesua ferrea L. seed oil-based epoxy resins. J. Appl. Polym. Sci. 2010, 118, 128-134. [CrossRef]

74. Mahapatra, S.S.; Karak, N. Synthesis and characterization of polyesteramide resins from Nahar seed oil for surface coating applications. Prog. Org. Coat. 2004, 51, 103-108. [CrossRef]

75. Dutta, S.; Karak, N. Synthesis, characterization of poly(urethane amide) resins from Nahar seed oil for surface coating applications. Prog. Org. Coat. 2005, 53, 147-152. [CrossRef]

76. Kalita, H.; Karak, N. Bio-based hyperbranched polyurethane/ $\mathrm{Fe}_{3} \mathrm{O}_{4}$ nanocomposites as shape memory materials. Polym. Adv. Technol. 2013, 24, 819-823. [CrossRef]

77. Dutta, S.; Karak, N.; Baruah, S. Jute-fiber-reinforced polyurethane green composites based on Mesua ferrea L. seed oil. J. Appl. Polym. Sci. 2010, 115, 843-850. [CrossRef]

78. Dutta, S.; Karak, N.; Jana, T. Evaluation of Mesua ferrea L. seed oil modified polyurethane paints. Prog. Org. Coat. 2009, 65, 131-135. [CrossRef]

79. Yadava, D.; Vasudev, S.; Singh, N.; Mohapatra, T.; Prabhu, K. Breeding major oil crops: Present status and future research needs. In Technological Innovations in Major World Oil Crops; Gupta, S.K., Ed.; Springer Science+Business Media, LLC: Berlin/Heidelberg, Germany, 2013; Volume 1, pp. 17-51. [CrossRef]

80. Oyman, Z.O.; Ming, W.; Linde, R.v.d. Oxidation of drying oils containing non-conjugated and conjugated double bonds catalyzed by a cobalt catalyst. Prog. Org. Coat. 2005, 54, 198-204. [CrossRef]

81. Biermann, U.; Butte, W.; Holtgrefe, R.; Feder, W.; Metzger, J.O. Esters of calendula oil and tung oil as reactive diluents for alkyd resins. Eur. J. Lipid Sci. Technol. 2010, 112, 103-109. [CrossRef]

82. Ribeiro da Silva, V.; Mosiewicki, M.A.; Yoshida, M.I.; Coelho da Silva, M.; Stefani, P.M.; Marcovich, N.E. Polyurethane foams based on modified tung oil and reinforced with rice husk ash I: Synthesis and physical chemical characterization. Polym. Test. 2013, 32, 438-445. [CrossRef]

83. Deka, D.C.; Basumatary, S. High quality biodiesel from yellow oleander (Thevetia peruviana) seed oil. Biomass Bioenergy 2011, 35, 1797-1803. [CrossRef]

84. Brooks, W.H. Jojoba-A north american desert shrub; its ecology, possible commercialization, and potential as an introduction into other arid regions. J. Arid Environ. 1978, 1, 227-236. [CrossRef]

85. Voirin, C.; Caillol, S.; Sadavarte, N.V.; Tawade, B.V.; Boutevin, B.; Wadgaonkar, P.P. Functionalization of cardanol: Towards biobased polymers and additives. Polym. Chem. 2014, 5, 3142-3162. [CrossRef]

86. Ma, H.-X.; Li, J.-J.; Qiu, J.-J.; Liu, Y.; Liu, C.-M. Renewable cardanol-based star-shaped prepolymer containing a phosphazene core as a potential biobased green fire-retardant coating. ACS Sustain. Chem. Eng. 2017, 5, 350-359. [CrossRef]

87. Kozubek, A.; Zarnowski, R.; Stasiuk, M.; Gubernator, J. Natural amphiphilic phenols as bioactive compounds. Cell. Mol. Biol. Lett. 2001, 6, 351-355. 
88. Kanehashi, S.; Yokoyama, K.; Masuda, R.; Kidesaki, T.; Nagai, K.; Miyakoshi, T. Preparation and characterization of cardanol-based epoxy resin for coating at room temperature curing. J. Appl. Polym. Sci. 2013, 130, 2468-2478. [CrossRef]

89. Liu, R.; Zhang, X.; Zhu, J.; Liu, X.; Wang, Z.; Yan, J. UV-curable coatings from multiarmed cardanol-based acrylate oligomers. ACS Sustain. Chem. Eng. 2015, 3, 1313-1320. [CrossRef]

90. Bo, C.; Hu, L.; Jia, P.; Liang, B.; Zhou, J.; Zhou, Y. Structure and thermal properties of phosphorus-containing polyol synthesized from cardanol. RSC Adv. 2015, 5, 106651-106660. [CrossRef]

91. Kathalewar, M.; Sabnis, A. Preparation of novel CNSL-based urethane polyol via nonisocyanate route: Curing with melamineformaldehyde resin and structure-property relationship. J. Appl. Polym. Sci. 2015, 132, 41391. [CrossRef]

92. Zhang, M.; Zhang, J.; Chen, S.; Zhou, Y. Synthesis and fire properties of rigid polyurethane foams made from a polyol derived from melamine and cardanol. Polym. Degrad. Stabil. 2014, 110, 27-34. [CrossRef]

93. Patel, C.J.; Mannari, V. Air-drying bio-based polyurethane dispersion from cardanol: Synthesis and characterization of coatings. Prog. Org. Coat. 2014, 77, 997-1006. [CrossRef]

94. Suresh, K.I. Rigid polyurethane foams from cardanol: Synthesis, structural characterization, and evaluation of polyol and foam properties. ACS Sustain. Chem. Eng. 2013, 1, 232-242. [CrossRef]

95. Kavalek, M.; Havrland, B.; Ivanova, T.; Hutla, P.; Skopec, P. Utilization of Jatropha Curcas L. seed cake for production of solid biofuels. In Proceedings of the 12th International Scientific Conference Engineering for Rural Development, Jelgava, Latvia, 23-24 May 2013; pp. 536-540.

96. Patil, C.K.; Rajput, S.D.; Marathe, R.J.; Kulkarni, R.D.; Phadnis, H.; Sohn, D.; Mahulikar, P.P.; Gite, V.V. Synthesis of bio-based polyurethane coatings from vegetable oil and dicarboxylic acids. Prog. Org. Coat. 2017, 106, 87-95. [CrossRef]

97. Pfister, D.P.; Xia, Y.; Larock, R.C. Recent advances in vegetable oil-based polyurethanes. ChemSusChem 2011, 4, 703-717. [CrossRef]

98. Shirke, A.G.; Dholakiya, B.Z.; Kuperkar, K. Enhancement of physico-chemical and anti-corrosive properties of tung oil based polyurethane coating via modification using anhydrides and inorganic acid. Surf. Interfaces 2019, 15, 180-190. [CrossRef]

99. Alagi, P.; Ghorpade, R.; Jang, J.H.; Patil, C.; Jirimali, H.; Gite, V.; Hong, S.C. Functional soybean oil-based polyols as sustainable feedstocks for polyurethane coatings. Ind. Crop. Prod. 2018, 113, 249-258. [CrossRef]

100. Alagi, P.; Ghorpade, R.; Jang, J.H.; Patil, C.; Jirimali, H.; Gite, V.; Hong, S.C. Controlled hydroxyl functionality of soybean oil-based polyols for polyurethane coatings with improved anticorrosion properties. Macromol. Res. 2018, 26, 696-703. [CrossRef]

101. Alagi, P.; Choi, Y.J.; Hong, S.C. Preparation of vegetable oil-based polyols with controlled hydroxyl functionalities for thermoplastic polyurethane. Eur. Polym. J. 2016, 78, 46-60. [CrossRef]

102. Alagi, P.; Choi, Y.J.; Seog, J.; Hong, S.C. Efficient and quantitative chemical transformation of vegetable oils to polyols through a thiol-ene reaction for thermoplastic polyurethanes. Ind. Crop. Prod. 2016, 87, 78-88. [CrossRef]

103. Patil, C.K.; Jirimali, H.D.; Mahajan, M.S.; Paradeshi, J.S.; Chaudhari, B.L.; Gite, V.V. Functional anti-corrosive and anti-bacterial surface coatings based on mercaptosuccinic and thiodipropionic acids and algae oil as renewable feedstock. React. Funct. Polym. 2019, 139, 142-152. [CrossRef]

104. Patil, C.K.; Jirimali, H.D.; Paradeshi, J.S.; Chaudhari, B.L.; Gite, V.V. Functional antimicrobial and anticorrosive polyurethane composite coatings from algae oil and silver doped egg shell hydroxyapatite for sustainable development. Prog. Org. Coat. 2019, 128, 127-136. [CrossRef]

105. Ahmad, S.; Ashraf, S.M.; Sharmin, E.; Zafar, F.; Hasnat, A. Studies on ambient cured polyurethane modified epoxy coatings synthesized from a sustainable resource. Prog. Cryst. Growth Charact. Mater. 2002, 45, 83-88. [CrossRef]

106. Sharmin, E.; Ashraf, S.M.; Ahmad, S. Synthesis, characterization, antibacterial and corrosion protective properties of epoxies, epoxy-polyols and epoxy-polyurethane coatings from linseed and Pongamia glabra seed oils. Int. J. Biol. Macromol. 2007, 40, 407-422. [CrossRef] [PubMed]

107. Akram, D.; Sharmin, E.; Ahmad, S. Development and characterization of boron incorporated linseed oil polyurethanes. J. Appl. Polym. Sci. 2010, 116, 499-508. [CrossRef]

108. Sharmin, E.; Zafar, F.; Akram, D.; Ahmad, S. Plant oil polyol nanocomposite for antibacterial polyurethane coating. Prog. Org. Coat. 2013, 76, 541-547. [CrossRef]

109. Pouladi, J.; Mirabedini, S.M.; Eivaz Mohammadloo, H.; Rad, N.G. Synthesis of novel plant oil-based isocyanate-free urethane coatings and study of their anti-corrosion properties. Eur. Polym. J. 2021, 153, 110502. [CrossRef]

110. Ahmad, S.; Ashraf, S.M.; Hasnat, A.; Yadav, S.; Jamal, A. Studies on urethane-modified alumina-filled polyesteramide anticorrosive coatings cured at ambient temperature. J. Appl. Polym. Sci. 2001, 82, 1855-1865. [CrossRef]

111. Paraskar, P.M.; Prabhudesai, M.S.; Kulkarni, R.D. Synthesis and characterizations of air-cured polyurethane coatings from vegetable oils and itaconic acid. React. Funct. Polym. 2020, 156, 104734. [CrossRef]

112. Shaik, M.R.; Alam, M.; Alandis, N.M. Development of sustainable resource based poly(urethane-etheramide)/Fe $\mathrm{O}_{3}$ nanocomposite as anticorrosive coating materials. J. Polym. Eng. 2015, 35, 905-916. [CrossRef]

113. Riaz, U.; Ashraf, S.M.; Ahmad, S. Comparative study of polyaniline and poly(1-naphthylamine) dispersed oil polyurethane coatings. Anti-Corros. Methods Mater. 2008, 55, 308-316. [CrossRef]

114. Ahmad, S.; Zafar, F.; Sharmin, E.; Garg, N.; Kashif, M. Synthesis and characterization of corrosion protective polyurethanefattyamide/silica hybrid coating material. Prog. Org. Coat. 2012, 73, 112-117. [CrossRef]

115. Yücedag, F.; Atalay-Oral, C.; Erkal, S.; Sirkecioglu, A.; Karasartova, D.; Sahin, F.; Tantekin-Ersolmaz, S.B.; Güner, F.S. Antibacterial oil-based polyurethane films for wound dressing applications. J. Appl. Polym. Sci. 2010, 115, 1347-1357. [CrossRef] 
116. Naik, R.B.; Ratna, D.; Singh, S.K. Synthesis and characterization of novel hyperbranched alkyd and isocyanate trimer based high solid polyurethane coatings. Prog. Org. Coat. 2014, 77, 369-379. [CrossRef]

117. Marathe, R.; Tatiya, P.; Chaudhari, A.; Lee, J.; Mahulikar, P.; Sohn, D.; Gite, V. Neem acetylated polyester polyol-Renewable source based smart PU coatings containing quinoline (corrosion inhibitor) encapsulated polyurea microcapsules for enhance anticorrosive property. Ind. Crop. Prod. 2015, 77, 239-250. [CrossRef]

118. Chaudhari, A.; Gite, V.; Rajput, S.; Mahulikar, P.; Kulkarni, R. Development of eco-friendly polyurethane coatings based on neem oil polyetheramide. Ind. Crop. Prod. 2013, 50, 550-556. [CrossRef]

119. Chaudhari, A.B.; Anand, A.; Rajput, S.D.; Kulkarni, R.D.; Gite, V.V. Synthesis, characterization and application of Azadirachta indica juss (neem oil) fatty amides (AIJFA) based polyurethanes coatings: A renewable novel approach. Prog. Org. Coat. 2013, 76, 1779-1785. [CrossRef]

120. Chaudhari, A.; Kuwar, A.; Mahulikar, P.; Hundiwale, D.; Kulkarni, R.; Gite, V. Development of anticorrosive two pack polyurethane coatings based on modified fatty amide of Azadirachta indica Juss oil cured at room temperature-A sustainable resource. RSC Adv. 2014, 4, 17866-17872. [CrossRef]

121. Chaudhari, A.; Kulkarni, R.; Mahulikar, P.; Sohn, D.; Gite, V. Development of PU coatings from neem oil based alkyds prepared by the monoglyceride route. J. Am. Oil Chem. Soc. 2015, 92, 733-741. [CrossRef]

122. Ahmadi, Y.; Ahmad, S. Surface-active antimicrobial and anticorrosive oleo-polyurethane/graphene oxide nanocomposite coatings: Synergistic effects of in-situ polymerization and $\pi-\pi$ interaction. Prog. Org. Coat. 2019, 127, 168-180. [CrossRef]

123. Ranade, S.; Neelakantan, L. Exploring in situ integration of pongamia oil to improve barrier properties of polyurethane coatings. J. Appl. Polym. Sci. 2020, 137, 49553. [CrossRef]

124. Alam, M.; Alandis, N.M. Development of poly(urethane esteramide) coatings from Pongamia glabra oil as anticorrosive applications. Int. J. Polym. Anal. Charact. 2015, 20, 330-343. [CrossRef]

125. Alam, M.; Alandis, N.M.; Ahmad, N.; Naushad, M. Synthesis and characterization of poly(urethane-ether azomethine) fatty amide based corrosion resistant coatings from Pongamia glabra oil: An eco-friendly approach. J. Chem. 2016, 2016, 5623126. [CrossRef]

126. Zafar, F.; Kashif, M.; Sharmin, E.; Ahmad, S. Studies on boron containing poly(urethane fattyamide). Macromol. Symp. 2010, 290, 79-84. [CrossRef]

127. Siyanbola, T.O.; Neelambaram, P.; Mohanty, S.; Somisetti, V.; Basak, P.; Narayan, R.; Kothapalli, R.V.S.N. The effects of carbonized Eucalyptus globulus leaves on castor seed oil based urethane coating system. Prog. Org. Coat. 2019, 131, 42-48. [CrossRef]

128. Bhosale, N.; Shaik, A.; Mandal, S.K. Synthesis and characterization of castor oil based hybrid polymers and their polyurethaneurea/silica coatings. RSC Adv. 2015, 5, 103625-103635. [CrossRef]

129. Gite, V.V.; Kulkarni, R.D.; Hundiwale, D.G.; Kapadi, U.R. Synthesis and characterisation of polyurethane coatings based on trimer of isophorone diisocyanate (IPDI) and monoglycerides of oils. Surf. Coat. Int. B Coat. Trans. 2006, 89, 117-122. [CrossRef]

130. Shaik, A.; Narayan, R.; Raju, K.V.S.N. Synthesis and properties of siloxane-crosslinked polyurethane-urea/silica hybrid films from castor oil. J. Coat. Technol. Res. 2014, 11, 397-407. [CrossRef]

131. Bakhshi, H.; Yeganeh, H.; Yari, A.; Nezhad, S.K. Castor oil-based polyurethane coatings containing benzyl triethanol ammonium chloride: Synthesis, characterization, and biological properties. J. Mater. Sci. 2014, 49, 5365-5377. [CrossRef]

132. Siyanbola, T.O.; Enishetty, R.; Kumar, R.; James, O.O.; Olasehinde, G.I.; Kaki, S.; Narayan, R.; Raju, K.V.S.N. Specific crosslinking effects of poly(epichlorohydrin)-triol on urethane polymer matrix of castor seed oil-based coatings. J. Coat. Technol. Res. 2021, 18, 129-141. [CrossRef]

133. Morsi, S.M.M.; Mohamed, H.A.; Abdel Ghany, N.A. Development of advanced-functional polyurethane/red iron oxide composites as protective one coating systems for steel. Prog. Org. Coat. 2019, 136, 105236. [CrossRef]

134. Akram, D.; Sharmin, E.; Ahmad, S. Synthesis, characterization and corrosion protective properties of boron-modified polyurethane from natural polyol. Prog. Org. Coat. 2008, 63, 25-32. [CrossRef]

135. Nardeli, J.V.; Fugivara, C.S.; Taryba, M.; Montemor, M.F.; Benedetti, A.V. Biobased self-healing polyurethane coating with Zn micro-flakes for corrosion protection of AA7475. Chem. Eng. J. 2021, 404, 126478. [CrossRef]

136. Nardeli, J.V.; Fugivara, C.S.; Taryba, M.; Montemor, M.F.; Ribeiro, S.J.L.; Benedetti, A.V. Novel healing coatings based on natural-derived polyurethane modified with tannins for corrosion protection of AA2024-T3. Corros. Sci. 2020, 162, 108213. [CrossRef]

137. Nardeli, J.V.; Fugivara, C.S.; Pinto, E.R.P.; Polito, W.L.; Messaddeq, Y.; Ribeiro, S.J.L.; Benedetti, A.V. Preparation of polyurethane monolithic resins and modification with a condensed tannin-yielding self-healing property. Polymers 2019, 11, 1890. [CrossRef] [PubMed]

138. Uscátegui, Y.L.; Arévalo, F.R.; Díaz, L.E.; Cobo, M.I.; Valero, M.F. Microbial degradation, cytotoxicity and antibacterial activity of polyurethanes based on modified castor oil and polycaprolactone. J. Biomater. Sci. Polym. Ed. 2016, 27, 1860-1879. [CrossRef]

139. Mohamed, H.A.; Badran, B.M.; Rabie, A.M.; Morsi, S.M.M. Synthesis and characterization of aqueous (polyurethane/aromatic polyamide sulfone) copolymer dispersions from castor oil. Prog. Org. Coat. 2014, 77, 965-974. [CrossRef]

140. Mohamed, H.A.; Morsi, S.M.M.; Badran, B.M.; Rabie, A.M. Eco-friendly protective coatings based on poly(urethane sulfone amide) dispersions for carbon steel. J. Coat. Technol. Res. 2017, 14, 437-446. [CrossRef]

141. Shaik, M.R.; Alam, M.; Alandis, N.M. Development of castor oil based poly(urethane-esteramide)/TiO 2 nanocomposites as anticorrosive and antimicrobial coatings. J. Nanomater. 2015, 2015, 745217. [CrossRef] 
142. Akram, D.; Hakami, O.; Sharmin, E.; Ahmad, S. Castor and linseed oil polyurethane/TEOS hybrids as protective coatings: A synergistic approach utilising plant oil polyols, a sustainable resource. Prog. Org. Coat. 2017, 108, 1-14. [CrossRef]

143. Pathak, R.; Kathalewar, M.; Wazarkar, K.; Sabnis, A. Non-isocyanate polyurethane (NIPU) from tris-2-hydroxy ethyl isocyanurate modified fatty acid for coating applications. Prog. Org. Coat. 2015, 89, 160-169. [CrossRef]

144. Akintayo, C.O.; Akintayo, E.T.; Ziegler, T. Studies on newly developed urethane modified polyetheramide coatings from Albizia benth oil. Prog. Org. Coat. 2011, 71, 89-97. [CrossRef]

145. Huang, Y.; Pang, L.; Wang, H.; Zhong, R.; Zeng, Z.; Yang, J. Synthesis and properties of UV-curable tung oil based resins via modification of Diels-Alder reaction, nonisocyanate polyurethane and acrylates. Prog. Org. Coat. 2013, 76, 654-661. [CrossRef]

146. Raychura, A.J.; Dholakiya, B.Z.; Patel, K.I.; Jauhari, S. Development of non-traditional vegetable-oil-based two-pack polyurethane for wood-finished coating: An alternative approach. ChemistrySelect 2018, 3, 10837-10842. [CrossRef]

147. Raychura, A.J.; Jauhari, S.; Dholakiya, B.Z. Development of wood protective polyurethane coatings from mahua oil-based polyetheramide polyol: A renewable approach. Soft Mater. 2018, 16, 209-219. [CrossRef]

148. Raychura, A.J.; Jauhari, S.; Patel, K.I.; Dholakiya, B.Z. A renewable approach toward the development of mahua oil-based wood protective polyurethane coatings: Synthesis and performance evaluation. J. Appl. Polym. Sci. 2018, 135, 46722. [CrossRef]

149. Siyanbola, T.O.; Sasidhar, K.; Anjaneyulu, B.; Kumar, K.P.; Rao, B.V.S.K.; Narayan, R.; Olaofe, O.; Akintayo, E.T.; Raju, K.V.S.N. Anti-microbial and anti-corrosive poly(ester amide urethane) siloxane modified ZnO hybrid coatings from Thevetia peruviana seed oil. J. Mater. Sci. 2013, 48, 8215-8227. [CrossRef]

150. Siyanbola, T.O.; Sasidhar, K.; Rao, B.V.S.K.; Narayan, R.; Olaofe, O.; Akintayo, E.T.; Raju, K.V.S.N. Development of functional polyurethane-ZnO hybrid nanocomposite coatings from Thevetia peruviana seed oil. J. Am. Oil Chem. Soc. 2015, 92, 267-275. [CrossRef]

151. Athawale, V.; Shetty, N. Synthesis and characterisation of low-cost cardanol polyurethanes. Pigment. Resin Technol. 2010, 39, 9-14. [CrossRef]

152. Balgude, D.; Sabnis, A.; Ghosh, S.K. Synthesis and characterization of cardanol based aqueous 2K polyurethane coatings. Eur. Polym. J. 2016, 85, 620-634. [CrossRef]

153. Alam, M.; Alandis, N.M. Microwave-assisted preparation of urethane-modified polyetheramide coatings from Jatropha seed oil. High Perform. Polym. 2012, 24, 538-545. [CrossRef]

154. Alam, M.; Alandis, N.M.; Ahmad, N.; Alam, M.A.; Sharmin, E. Jatropha seed oil derived poly(esteramide-urethane)/fumed silica nanocomposite coatings for corrosion protection. Open Chem. 2019, 17, 206-219. [CrossRef]

155. Sørensen, P.A.; Kiil, S.; Dam-Johansen, K.; Weinell, C.E. Anticorrosive coatings: A review. J. Coat. Technol. Res. 2009, 6, 135-176. [CrossRef]

156. Alam, M.; Ray, A.R.; Ashraf, S.M.; Ahmad, S. Synthesis, characterization and performance of amine modified linseed oil fatty amide coatings. J. Am. Oil Chem. Soc. 2009, 86, 573-580. [CrossRef]

157. Somisetti, V.; Narayan, R.; Kothapalli, R.V.S.N. Multifunctional polyurethane coatings derived from phosphated cardanol and undecylenic acid based polyols. Prog. Org. Coat. 2019, 134, 91-102. [CrossRef]

158. Voit, B. Hyperbranched polymers-All problems solved after 15 years of research? J. Polym. Sci. Part A Polym. Chem. 2005, 43, 2679-2699. [CrossRef]

159. Bechi, D.M.; Luca, M.A.d.; Martinelli, M.; Mitidieri, S. Organic-inorganic coatings based on epoxidized castor oil with APTES/TIP and TEOS/TIP. Prog. Org. Coat. 2013, 76, 736-742. [CrossRef]

160. Akram, D.; Sharmin, E.; Ahmad, S. Synthesis and characterization of boron incorporated polyester polyol from linseed oil: A sustainable material. Macromol. Symp. 2009, 277, 130-137. [CrossRef]

161. Ong, H.R.; Ramli, R.; Khan, M.M.R.; Yunus, R.M. The influence of CuO nanoparticle on non-edible rubber seed oil based alkyd resin preparation and its antimicrobial activity. Prog. Org. Coat. 2016, 101, 245-252. [CrossRef]

162. Esser-Kahn, A.P.; Odom, S.A.; Sottos, N.R.; White, S.R.; Moore, J.S. Triggered release from polymer capsules. Macromolecules 2011, 44, 5539-5553. [CrossRef]

163. Cho, S.H.; White, S.R.; Braun, P.V. Self-healing polymer coatings. Adv. Mater. 2009, 21, 645-649. [CrossRef]

164. Zhu, D.Y.; Rong, M.Z.; Zhang, M.Q. Self-healing polymeric materials based on microencapsulated healing agents: From design to preparation. Prog. Polym. Sci. 2015, 49-50, 175-220. [CrossRef]

165. Suryanarayana, C.; Rao, K.C.; Kumar, D. Preparation and characterization of microcapsules containing linseed oil and its use in self-healing coatings. Prog. Org. Coat. 2008, 63, 72-78. [CrossRef]

166. Samadzadeh, M.; Boura, S.H.; Peikari, M.; Kasiriha, S.M.; Ashrafi, A. A review on self-healing coatings based on micro/nanocapsules. Prog. Org. Coat. 2010, 68, 159-164. [CrossRef]

167. Tatiya, P.D.; Hedaoo, R.K.; Mahulikar, P.P.; Gite, V.V. Novel polyurea microcapsules using dendritic functional monomer: Synthesis, characterization, and its use in self-healing and anticorrosive polyurethane coatings. Ind. Eng. Chem. Res. 2013, 52, 1562-1570. [CrossRef]

168. Vasilev, K.; Cook, J.; Griesser, H.J. Antibacterial surfaces for biomedical devices. Expert Rev. Med. Devices $2009,6,553-567$. [CrossRef] [PubMed]

169. Tiller, J.C. Antimicrobial Surfaces. In Bioactive Surfaces. Advances in Polymer Science; Börner, H.G., Lutz, J.-F., Eds.; Springer: Berlin/Heidelberg, Germany, 2010; Volume 240. [CrossRef] 
170. Yari, A.; Yeganeh, H.; Bakhshi, H.; Gharibi, R. Preparation and characterization of novel antibacterial castor oil-based polyurethane membranes for wound dressing application. J. Biomed. Mater. Res. A 2014, 102, 84-96. [CrossRef] [PubMed]

171. Mandal, B.; Majumdar, S.G.; Maity, C.R. Chemical and nutritional evaluation of Pongamia glabra oil and Acacia auriculaeformis oil. J. Am. Oil Chem. Soc. 1984, 61, 1447-1449. [CrossRef]

172. Sharmin, E.; Akram, D.; Zafar, F.; Ashraf, S.M.; Ahmad, S. Plant oil polyol based poly(ester urethane) metallohybrid coatings. Prog. Org. Coat. 2012, 73, 118-122. [CrossRef]

173. Zafar, F.; Ashraf, S.M.; Ahmad, S. In situ development of Zn/Cd-incorporated poly(esteramide-urethane) from sustainable resource. J. Appl. Polym. Sci. 2008, 110, 584-593. [CrossRef]

174. Thakur, S.; Barua, S.; Karak, N. Self-healable castor oil based tough smart hyperbranched polyurethane nanocomposite with antimicrobial attributes. RSC Adv. 2015, 5, 2167-2176. [CrossRef]

175. Chamberlain, N.R.; Mehrtens, B.G.; Xiong, Z.; Kapral, F.A.; Boardman, J.L.; Rearick, J.I. Correlation of carotenoid production, decreased membrane fluidity, and resistance to oleic acid killing in Staphylococcus aureus 18Z. Infect. Immun. 1991, 59, $4332-4337$. Available online: http:/ / iai.asm.org/content/59/12/4332.abstract (accessed on 1 February 2021). [CrossRef] [PubMed]

176. Sharma, V.K.; Yngard, R.A.; Lin, Y. Silver nanoparticles: Green synthesis and their antimicrobial activities. Adv. Colloid Interface Sci. 2009, 145, 83-96. [CrossRef] [PubMed]

177. Kvítek, L.; Panáček, A.; Soukupová, J.; Kolář, M.; Večeřová, R.; Prucek, R.; Holecová, M.; Zbořil, R. Effect of surfactants and polymers on stability and antibacterial activity of silver nanoparticles (NPs). J. Phys. Chem. C 2008, 112, 5825-5834. [CrossRef]

178. Fu, H.; Wang, Y.; Li, X.; Chen, W. Synthesis of vegetable oil-based waterborne polyurethane/silver-halloysite antibacterial nanocomposites. Compos. Sci. Technol. 2016, 126, 86-93. [CrossRef]

179. Liang, H.; Liu, L.; Lu, J.; Chen, M.; Zhang, C. Castor oil-based cationic waterborne polyurethane dispersions: Storage stability, thermo-physical properties and antibacterial properties. Ind. Crop. Prod. 2018, 117, 169-178. [CrossRef] 